JUN ? 31949 


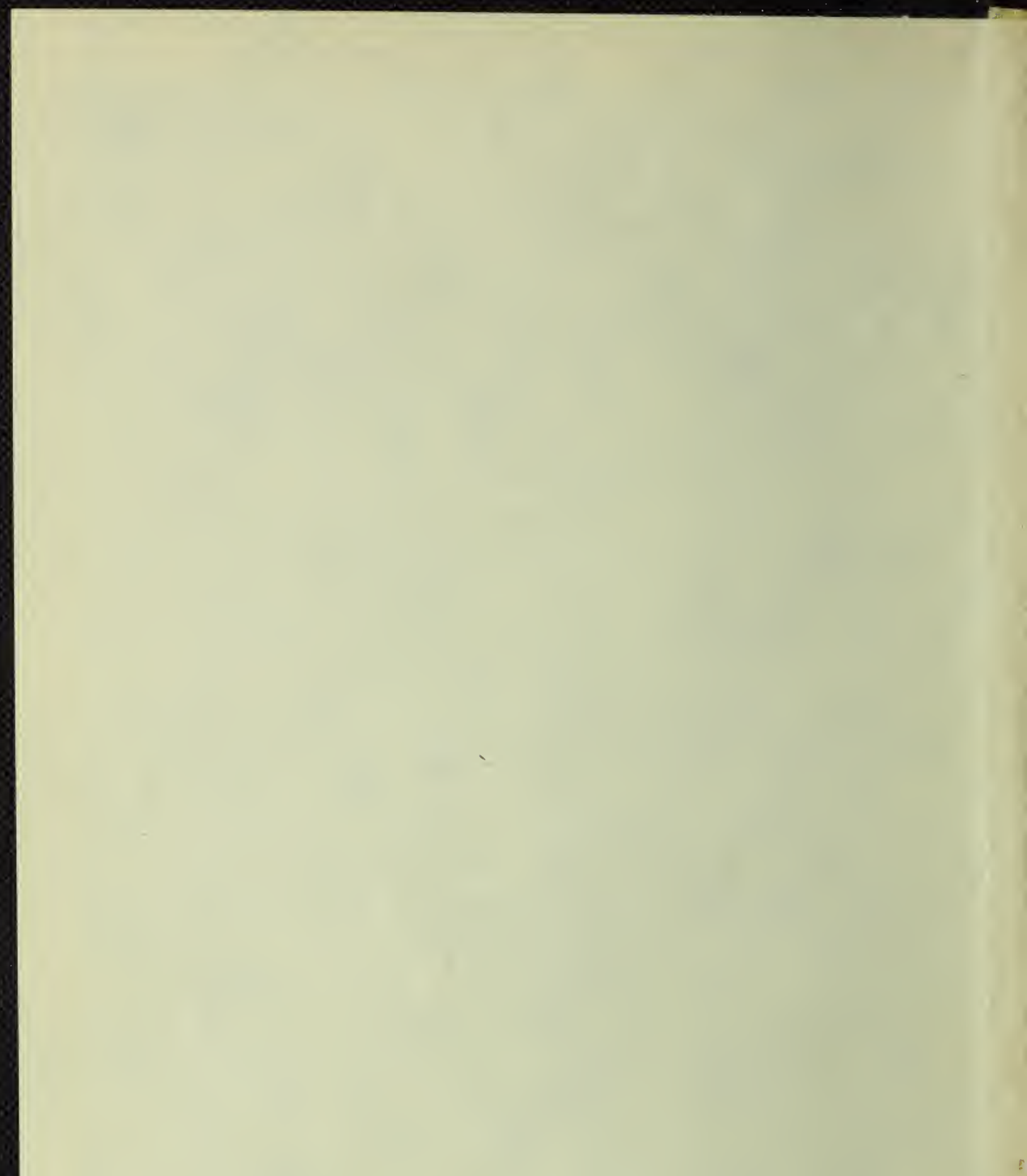


SCIENCE AND ART MUSEUII, IUUBLIN.

A LIST

OF

\section{IRISH BIRDS}

SHOWING

THE SPECIES CONTAINED

IN THE

SCIENCE ANI) ART MUSEUII, DUBLIN.

BY

ALEXANDER G. MORE, F.LS., F.R.S.E., M.R.I.A.

IATE CURATOR OF THE NATURAL IISTORY DEPARTMENT.

[SECOND EDITION.]

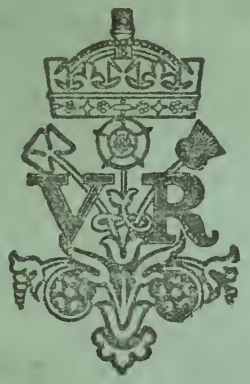

DUBLIN PRINTED FOR HER MAJESTY'S STATIONERY OFFICE,

ALEX. THOM \& CO. (LIMTtKD), 87, 88, \& 89, ABBEY-STREET,

THE QUREN'S PRINTING OFFICE;

AND SOLD AT THE MUSEUM OF SCIENCE AND ART, LEINSTER HOUSE.

1890. 


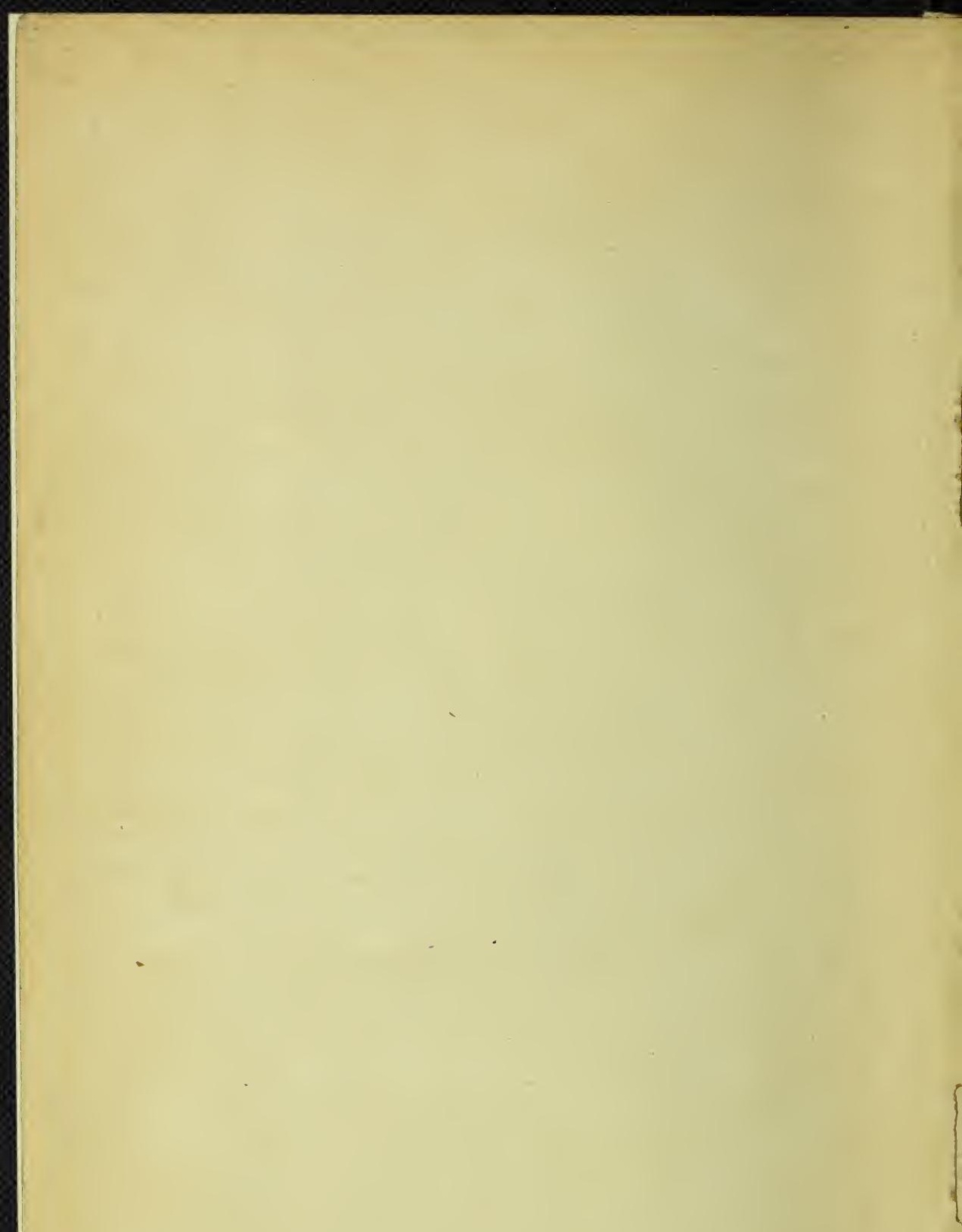





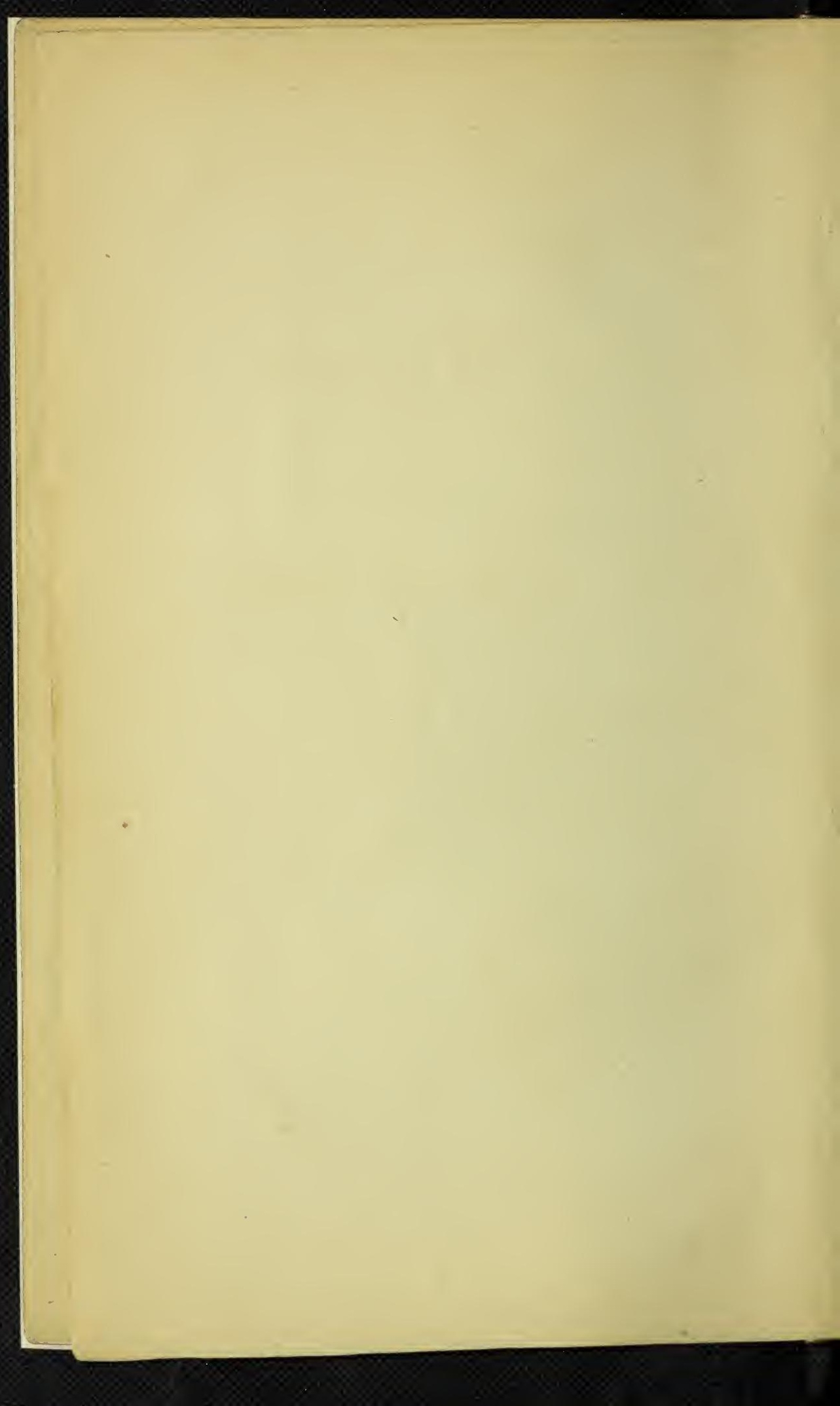




\section{SCIENCE AND ART MUSEUM, DUBLIN.}

A LIST

OF

\section{IRISH BIRDS}

SHOWING

THE SPECIES CONTAINED

IN THE

\section{SCIENCE AND ART MUSEUM, DUBLIN.}

BY

ALEXANDER G. MORE, F.L.S., F.R.S.E., M.R.I.A.

LATE CURATOR OW THE NATURAL HISTORY DEPARTMENT.

[SECOND EDITION.]

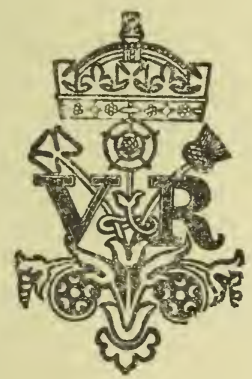

DUBLIN : PRINTED FOR HER MAJESTY'S STATIONERY OFFICE, ALEX. THOM \& CO. (LimiteD), 87, 88, \& 89, ABBEY-STREET,

THE QUERN'S PRINTING OFFICE;

AND SOLD AT THE MUSEUM OF SCIENCE AND ART, LEINSTER HOUSE.

1890.

Price Four Pence. 







\section{PREFACE}

TO SECOND EDITION.

THE previous edition of this list was the first of an official series of Catalogues of the Natural History Collections in the Science and Art Museum, now in course of preparation.

Hitherto the only published accounts of specimens contained in this department of the Museum have appeared in the Transactions or Proceedings of Learned Societies. Among such accounts, papers by the late Drs. Leith Adams and Carte on the Fossil Mammals of Ireland, Mr. W. F. Kirby's Catalogue of the Lepidopter a in the Museum, and Mr. Lydekker's Catalogue of the Vertebrate Fossils from the Sivaliks of India, are the most noteworthy.

It is hoped that the publication of these Catalogues will prove mutually beneficial to the public and to the Museum. The present edition of the List of Birds has been carefully revised by Mr. A. G. More, late Curator of the Museum, who is admitted to be the most competent authority on the subject.

A new feature in the Museum, since the first edition was published, will be found in the groups in glass cases, placed on the floor of the upper room, illustrating the life history of different species of Irish birds.

\section{BALL,}

Director, Science and Art Museum.

\section{Leinster House, Dublin.}

December, 1889. 


\section{INTRODUCTION.}

THE collection of Birds occupies the whole of the First Gallery of the Upper Room of the Natural History Department. The Irish Birds are kept separate, in cases 1 to 11 , and life-illustrations of many of the species will be found placed on the floor of the same room.

Besides the numerous specimens which have at various times been purchased or presented, our native series comprises three of the most important collections formed in Dublin, viz.:-those of the late T. W. Warren and of the late R. J. Montgomery, together with that of the Natural History Society of Dublin, which last was presented to the Museum in 1880. Many of these birds are mentioned by Thompson in his " Natural History of Ireland."

Instead of enumerating only the species which are contained in the Museum, it has been thought advisable to give a complete List of the Birds of Ireland, in which the species represented in the Museum are distinguished by their being printed in Egyptian sype, while the names of those which we do not possess are printed in Italics. The asterisk is used to indicate the Birds which breed in Ireland.

The names and order followed are those of the 4th Edition (by Newton and Saunders) of Yarrell's British Birds-the standard work on the subject.

Thompson's "Birds of Ireland" (1849-51), and Watters" "Natural History of the Birds of Ireland" (1853) are well known, and much information respecting Irish Birds will be found in the "Reports on the Migration of Birds," from 1881 to $\mathbf{1 8 8 7}$, and in "The Zoologist."

Dr. R. F. Scharff, the present Curator, has very kindly communicated to me many valuable items of information, especially regarding recent additions which he has made to the Museum.

A. G. MORE. 

Qperey- She thot hear liceorghing Co. Herry trbmany 1895 -(Lane and waler $z$ har th 2 nd 1895: hich hal. 1895, p. 1057. Another thol-al-bed bromore, Co.Corte IIth hay 1893 (Wich hal-1893,10.201) Gremland Talcon. - Lact trish specinin was shot on Aclill Laland loo. Mays, 12 th Secumber 1891 ( gaol. $1892,4.77$ ). 


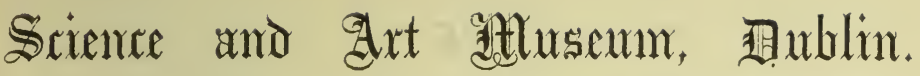

\section{A LISI' OF IRISH BIRDS.}

\section{ORDER-ACCIPITRES.}

\section{VULTURID}

Gyps fulvus (Gmel.) Griffon Vulture.

Once captured at Cork in the spring of 1843 . (Thompson).

This specimen is preserved in the Natural History Museum at Trinity College, Dublin.

\section{FALCONIDe.}

*Aquila chrysaetus (Linn.) Golden Eagle.

Decreasing. Still breeds very sparingly in the West and North of Ireland.

Aquila clanga (Pallas). Spotted Eagle.

Two were shot near Youghal, January, 1845. (Thompson). One of these is in the Trinity College Museum.

* Fallzetus albicilla (Linn.) White-tailed Eagle.-Sea-Eirgle.

Like the Golden Eagle, becoming very scarce. It is believed that a few pairs still breed in the West of Ireland; but, owing to poisoning, the Sea Eagle has become rarer than the Golden Eagle.

Pandion haliæetus (Linn.) Osprey.

Rare visitor, chiefly in autumn. There is, in the Museum, a fine specimen, recently obtained at Clontarf, close to Dublin.

Falco candicans (J. F. Gmel.) Greenland Falcon.

Native of America. Rare and uncertain winter visitor. Eight were captured, at different points along the western coast of Ireland, in the winter of 1883-4, of which three are. in the Museum, two of these, shot at the Tearaght Lighthouse, Kerry, having been presented by Mr. E. M'Carron. An old male was shot at the Skelligs Lighthouse, September 28, 1887. (Migration Report for 1887, p. 122).

The asterisk $(*)$ is used to indicate the species which breed in Ireland. 
ralco islandus (J. F. Gmel.) Iceland Falcon.

Like the former, a very rare winter visitor. The specimen in the Museum was obtained near Belmullet, co. Mayo, and has been kindly lent by Mr. H. J. Richards.

* Falco peregrinus (J. F. Gmel.) Peregrine Falcon.

Resident in small numbers. Breeds on the sea-cliffs all round the coast, and less numerously on the higher mountains.

Falco subbuteo (Linn.) Hobby.

Very rare summer visitor. Has occurred seven times in Ireland. (Zoologist, 1877, p. 472 ; and 1883, p. 122.)

Falco vespertinus (Linn.) Red-footed Falcon.

Once olutained in Wicklow, in the summer of 1832 . (Thompson.) This specimen is in the Museum, having formerly belonged to the late $\mathrm{Mr}$. T. W. Warren's collection.

* ralco asalon (Gmel.) Merlin.

Frequent, especially in the mountainous districts, where it breeds. Descends, in autumn, to the level country and bogs.

* Falco tinnunculus (Linn.) Kestrel.

General, and with the Sparrow Hawk, the most common species of Hawk. Most numerous in autumn.

Astur palumbarius (Linn.) Goshawk.

One was obtained in Longford in the autumn of 1846. (Watters.) One seen in Ballymanus Wood, in Wicklow, in the spring of 1870 . (Zoologist, 1870, p. 2283.) One, killed at Kilruddery, Wicklow, in 1844, is quoted by Sir R. Payne-Gallwey, from a note left by the late Dr. J. R. Kinahan. (Fowler in Ireland, p. 312.)

Astur atricapilus (Wils.) American Goshawk.

Native of America. One killed at Ballinacourte, county Tipperary, in Feb., 1870, was presented to the Museum by Mr. G. K. S. Massy Dawson. (1bis, 1870, p. 538.) Another was shot near Par'sonstown about same date. (A. B. Brooke, in Zoologist, 1871, p. 2524).

* Accipiter nisus (Limn.) Sparrow.Hawk.

Resident and common.

Milvus ictinus (Savigny). Kite.

Extremely rare. Has been observed five or six times. Only one Irish specimen is known. In his book, the "Fowler in Ireland," Sir R. Payne-Gallwey mentions having shot a young male Kite on the Cashen River in Kerry, in the winter of $1880-81$. 


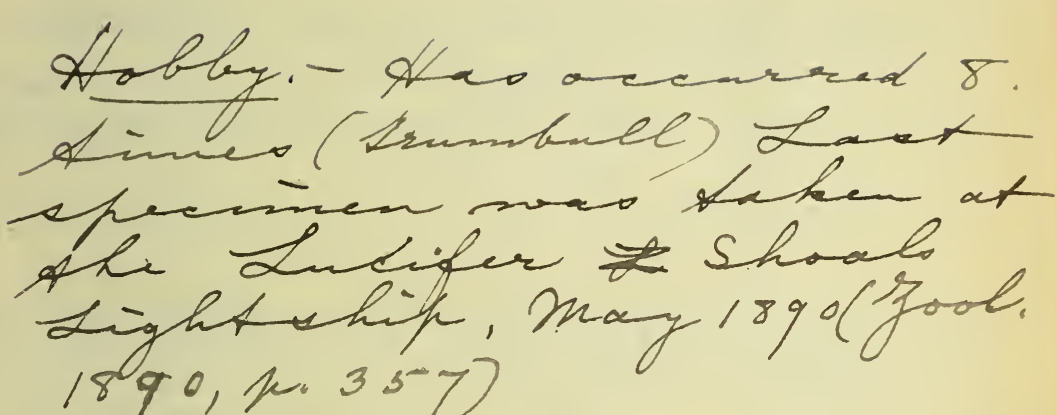

$1890,40.3577$

Haceo cenchis, haum Hesoer reatrell-maie once occured



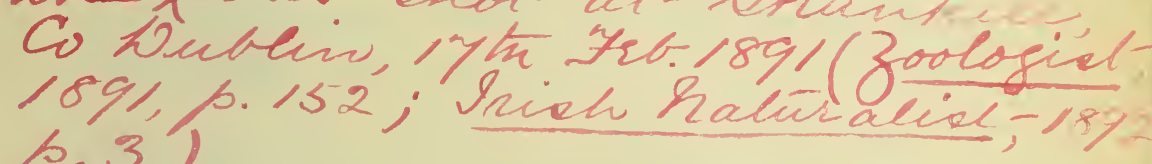
1.3) 
Rough-legged Buzzand- Wuothen oblainco at-Hoin Heace Co. Dongal hovember 1891 ( Fiell hareh 12 th 1892 ; sish hat: 1892, (3.44)

toncy Buzzand-One chat-in wexcend oct. 1892 ( hich hal: 1893, 6.25 ) a male o hat at Minterm abbey, leo. Weseford, 27 t Jum 1890 (3ool, 1890, 1.355)

inonlägis Atarier A male from tweoford $t$ a female from Wieblow are in the nuseum. Another was chor-at-BlenasBole Co. Wublin 3nd kuly $18 \% 3$ (Visin hat. 1893, p.253) 
Elanus ccruleus (Desf.) Black-winged Kite.

Has occurred once on the bog of Horsestown in the county Meath (Ibis, 1872, p. 471, Zoologist, 1875, p.4455), and is now in the possession of Sir John Dillon, at Lismullen.

* Buioo vulgaris (Leach.) Common Buzzard.

Decreasing and now become very rare as a breeding species. It occasionally occurs as a migrant in spring and autumn.

Buteo lagopus (Gmel.) Rough-legged Buzzard. Seven or

Very rare visitor in late autumn. Only times noticed in Ireland. One was shot in 1867 at Slyne Head, Galway, by the lighthouse-keeper, Mr. Redmond, as I lear'n from my friend, Mr. R. J. Ussher.

Pernis apivorus (Linn.) Honey Buzzard.

Very rare visitor in summer and autumn. The specimen in the Museum was obtained in Kildare in 1882.

*Circus aeruginosus (Linn.) Marsh Harrier.

Resident, hut has now become scarce and local. Still breeds in some of the bogs, especially in the midland counties, and along the shores of the Shannon.

* Circus cyaneus (Linn.) Hen Harrier.

Resident, now decreasing, but breeds on the moors and mountains in various parts of the country.

Circus cineraceus (Mont.) Montagu's Harrier. Sus

Very rare visitor in autumn. Has occurred times in Ireland; viz. :-At Bray, Oct., 1848. (Thompson, Vol. i., p. 427.) At the Scalp, Oct. 1, 1849. (Thompson, Vol. ii., p. 8.) Again in 1877 , at the Scalp. (Mr. E. Williams.) The last specimen is in the possession of Major Barton, at Straffan.

\section{STRIGIDR.}

* Asio otus (Linn.) Long-eared Owl.

Resident and frequent throughout the country.

Asio accipitrinus (Pallas). Short-eared Owl.

Regular visitor in winter.

scops giu (Scopoli). Scops-Owl.

Very rare visitor. Two are mentioned by Thompson. One obtained in Meath. Another in Wexford, April, 1847. One was captured at Belfast, 17 th November, 1883 , for the notice of which I am indebted to Mr. Blake Knox. A specimen labelled "Ireland," is in the Museum, from Mr. Warren's collection, but with no special locality attached. One shot in Wexford, May 31, 1889, has been presented to the Museum by Mr. F. R. Leigh. (Zoologist 1889, p. 313.) 
wyctea scandiaca (Linn.) Snowy Owl.

Very rare and uncertain winter visitor. One shot on Inishtrahull Island, Donegal, 19th November, 1882, was presented to the Museum by Mr. W. H. James, the Light. house keeper. One was shot at Dundrum, co. Down, January 18, 1889, as I am informed by Mr. Sheals, of Belfast, and Mr. H. Blake Knox in 1888 obtained a specimen from Belmullet, Mayo.

*Aluco flammeus (Linn.) Barn Owl.

Resident and generally distributed in small numbers.

\section{ORDER-PASSERES.}

\section{LANIIDE.}

Ianius excubltor (Linn.) Great Grey Shrike.

Rare and uncertain winter visitor. The two Grey Shrikes in the Museum, from counties Louth and Down, both have only one wing-bar.

Lanius collurio (Linn.) Red-backed Shrike.

Has once occurred. Near Belfast, 10th August, 1878. (Zoologist, 1878, p. 437.)

\section{MUSCICAPIDE.}

* Musclcapa grisola (Iinn.) Spotted Flycatcher.

Regular summer visitor, and generally distributed.

Muscicapa parva (Bechst). Red-breasted Flycatcher.

Has once occurred. At Arklow South Lightship, 23rd October, 1887. (Zoologist, 1888, p. 390, and Migration Report for 1887, p. 124.)

Muscicapa atricapilla (Linn.) Pied Flycatcher.

Very rare visitor. Has several times been taken at lighthouses in autumn-e.g., at 'Tearaght, September' 21, and at Fastnet, October 5, 1886. Again at the Fastnet, September 30,1888 , and at the Tuskar, September 28, 1888. (Zoologist, 1888, pp. 391 and 425.) The first Irish specimen was shot at Moyview, co. Sligo, April, 1875 (Zoologist, 1875, p. 4498), and was presented to the Museum by Mr. K. Warren.

\section{ORIOLIDE.}

orlolus galbala (Linn.) Golden Oriole.

Very rare summer visitor-chiefly to the South and East of Ireland. 
Snowy Owl- Ins Stavoy ohd on on Achiel ieand C. krayo bec (?) 1892 ( Wish Mines Wee. 14 会 1892 ; rech hal.-1893, p.25) Anothir Dhol-near Belmuled- Oo.mayo $13 \mathrm{th}$ wee. 1893 (wich hal:-1894, p.24)

M. parra. - A scased efaciom was daken by hor W. H. Janno at 20 th. Calto ben 1890' (Krambill). 
Inrdus higratorius (timn)

Americen Robin. One ohol-atHeringmounl, Shankile, Co. Nith Horence and ant- hessen thuth (3oolojicl 1891 1.219; hish rall: 1892 


\section{CinClide.}

*Cinclus aquaticus (Bechst.) Dipper.

Resident, and frequent in and near to the mountainous districts.

\section{IXID E.}

Pycnonotus capensis (Linn.) Gold-vented Thrush.

Has once occurred. Near Waterford, in January, 1838. (Thompson.) Formerly in the Trinity College Museum.

\section{TURDIDE.}

Turdus varius (Pallas). White's Thrush.

Has three times occurred. At Bandon, Cork, in December, 1842 (Thompson.) (This specimen, which has lost its head, is in the Trinity College Museum.) At Ballymahon, Longford, in the spring of 1867. (Zoologist, 1870, p. 2060.) Another shot at Westport, Mayo, January, 1885, has been presented to the Museum by Captain $R$. Ruttledge-Fair.

* Yurdus viscivorus (Linn.) Mistletoe Thrush.

Resident and now general. Is believed to have settled in [reland since 1800. Flocks are seen from July onwards.

* Turdus musicus (Linn.) Song Thrush.

Resident and common. Large numbers arrive in autumn and winter, when the bird is often captured at the Lighthouses.

Turdus nliacus (Linn.) Redwing.

A common winter visitor.

Turdus pilaris (Linn.) Fieldfare.

Regular winter visitor.

* Turdus merula (Linn.) Blackbird.

Resident and common. Its numbers are largely increased in autumn and winter, and it is often taken at the Lighthouses when migrating.

* Turdus torquatus (Linn.) Ring-Ouzel.

Summer visitor, frequenting, in limited numbers, the mountäinous districts throughout Ireland.

\section{SYLVIIDE.}

*Accentor modularis (Linn.) Hedge-Sparrow.

Resident and common. 
* Erithacus rubecula (Linn.) Redbreast.

Resident and common. Often taken at the Lighthouses when migrating.

[The Nightingale is recorded in the Zoologist, by Mr. Ussher, as having been once obtained; and $\mathrm{Mr}$. F. Rohu has kindly informed me that this single specimen, how in the Museum at Queen's College, Cork, was shot on the Lighthouse wall at the Old Head of Kinsale, on the 23rd September, 1876, but, as in the case of the Reed Warbler, I do not think that one visit of a common English bird is sufficient to give it a place on the Irish list.]

* Ruticilla phœenicurus (Linn.) Redstart.

Very rare visitor. Has, within the last few years, been found breeding at Powerscourt, Wicklow ; and has several times been captured at the Lighthouses, both in spring and autumn.

Ruticlla titys (Scopoli). Black Redstart.

Winter visitor, occurring in small numbers chiefly on or near to the coasts.

*saxicola rubicola (Linn.) Stonechat. Resident and common.

* Saxicola rubetra (Linn.) Whinchat.

Summer visitor in small numbers. Rare and local.

* Saxicola cenanthe (Linn.) Wheatear.

Summer visitor, common.

Hypolais icterina (Vieill.) Icterine Warbler.

Has once, or perhaps twice, occurred. The first Irish specimen, shot at Dunsinea, 8th June, 1856, was most liberally presented to the Museum by Mr. J. G. Rathborne (See Royal Dublin Society's Journal, i., p. 440). Another is recorded as having been observed by Mr. Allan Ellison. in Coollattin Park, Wicklow, on the 29th May, 1886, at nearly the same date when the bird was seen in Pembrokeshire (Zoologist, 1886, p. 333).

[Mr. Montgomery is recorded to have obtained a specimen of the Reed Warbler at Raheny, near Dublin, on the 21st December, 1843 (Thompson); and about the same date a Whitethroat and two Blackcaps.]

*Acrocephalus schœenobæenus (Linn.) Sedge Warbler. Regular summer visitor, and widely distributed. 
Sylvia curruca (timn) veser. Whilethroat. Htas once ocemes. AL-Yearaghl-Tock tighthōnee Co. herry 10l-oct. 1890 (Zoologial-18,1 s. 3No, Wich hat. 1892 , s.3)

Sylvia risana (Becket) Barred Warber. One oblained reas Belmuly Co. hayo 24 th - Sept. 1884 is how. in the Breveum, toublin (3oologist 1890.10 .310 ; Vish hat $1892,1.3)$ Phylioscopus supercilione (9.*. Sone) -ained; Al-Yearagh-Roek


1890 (3oologial -1891, 10.186; liah 1892,13 3) this epecinen is sivi in ins R. Rn. Barringlónó collectios? 
*Acrocephalus navius (Bodd.) Grasshopper Warbler.

Regular summer visitor. Rare and local, but breeds in the East and South of Ireland, and in Fermanagh. Quite recently the bird has been found also in Mayo (Zoologist, 1866, p. 366).

* sylvia rufa (Bodd.) Greater. Whitethroat.

Regular summer visitor, and widely distributed.

*syivia salicaria (Linn.) Garden Warbler.

Rare summer visitor, and very local. Has been found breeding in the counties of Antrim, Fermanagh, Tipperary, and probably Cork.

*Sylvia atricapila (Linn.) Blackcap.

Regular summer visitor in very small numbers. The nest has been found in the counties of Dublin, Wicklow, Tipperary, Waterford, and Mayo, and the bird probably breeds also in Antrim. Has several times occurred in winter.

Phylloscopus sibilatrix (Bechst.) Wood-Wren.

Very rare summer visitor. Has been obtained in Fermanagh and Dublin (Harting, Summer Migrants), in Donegal (Hart), and several times observed in Wicklow, in which last county it is believed to breed. (Zoologist, 1879, p. 341). A specimen from Colebrooke, presented by Sir Victor Brooke, and another from Donegal, presented by Mr. H. C. Hart, are in the Museum. A Wood-Wren was observed by Mr. R. Patterson, in the "Bog Meadows," near Belfast, on the 5th May, 1889.

* Phylloscopus trochilus (Linn.) Willow-Wren.

Summer visitor, common.

* Phylloscopus oollybita (Vieill.) Chiffchaff.

Summer visitor, frequent. Has occurred in winter.

* Regulus cristatus (Koch). Golden-crested Wren.

Resident and common. Often taken in large numbers at the Lighthouses when migrating.

Obs.-It is remarkable that the Fire-crested Wren has not yet been observed in Ireland, though it occurs nearly every winter in England.

\section{TrOGLODYTIDA:}

* Troglodytes parvulus (Koch). Wren.

Resident and cemmon. Often captured at the Lighthouses on migration. 


\section{Certhilde.}

* Certhia familiaris (Linn.) Tree-Creeper. Resident and frequent.

\section{PARIDE.}

* Parus major (Linn.) Great Titmouse. Resident and common.

* Parus caruleus (Linn.) Blue Titmouse. Resident and common.

* Parus ater (Linn.) Coal Titmouse.

Resident and common.

Parus palustris (Linn.) Marsh Titmouse.

Very rare. Has occurred in Antrim, Kildare, and Dublin. (Thompson.) Dr. Kinahan mentions having once shot, near Donnybrook, a hen and three young ones, which were probably reared in the vicinity. (Nat. Hist. Review, Vol. ii. ; Proceedings, p, 24).

* Acredula caudata (Linn.) Long-tailed Titmouse.

Resident and widely distributed.

\section{A.MPELIDA.}

Ampelis garrulus (Linn.) Waxwing.

Rare and irregular winter visitor.

\section{Motacillide.}

*Motacilla lugubris (Temm.) Pied Wagtail.

Resident and common. Partially migratory.

Motacilla alba (Linn.) White Wagtail.

Very rare summer visitor. Has been once obtained by Mr. R. Warren, near Moyview, on the 25th April, 1851. (Dublin Nat. Hist. Soc. Proceedings, Vol. iii., p. 115). Mr. Blake Knox records having once observed it near Wexford. (Zoologist, 1866, p. 95.) It was seen at Roundwood by the late Dr. R. Ball. (Thompson.)

* Motacilla sulphurea (Bechst.) Grey Wagtail.

Resident in small number's, and not unfrequent, but local.

* Motacilla Raii (Bonap.) Yellow Wagtail.

Summer visitor in small numbers, and very local. Breeds regularly about Lough Neagh, and occurs every autumn in the vicinity of Dublin, where also the nest lias been once found by Mr. E. Williams. Mr. A. Ellison has several times seen it near Shillelagh, Wicklow, in the spring. 
Haroh Hit- He- is now years eince one was obläined in heland, and ! am holvied o thinte thal = il-has rever hed ni this conulis.

Wasuining- Hive rearded in 1893 one in 1894 and two in 189. Whic-Wagtail-Ins Robert-Warrew
obtained one and oberved Another on Bartragh island, Nillala Bay Chay 0.29th aprie 1893 / Mich hal: $1593.15,2001$ 
Alauda brachydadyeu Liol,

Short = toed atark. Once oblainid

ii. Ireland. Al- the Bladerock


Zodogiel -1890, p. 186; \&ien ral: 1892, (1).3) 
*Anthus pratensis (Linn.) Meadow-Pipit.

Resident and common. Partially migratory.

Obs.-The Tree-Pipit is thought to have been observed at

Ballitore, Raheny, Portmarnock, and Irishtown, but no specimen has been obtained in Treland. The Rer. Dr. Benson tells me that, since he has heard the Tree-Pipit singing in North Wales, he feels some doubt as to the correctness of his identification of the bird which he had observed near Dublin.

* Anthus obscurus (Lath.) Rock-Pipit.

Resident, and generally distributed on the sea-coast.

\section{Alaudide.}

*Alauda arvensis (Linn.) Skylark.

Resident and numerous. Partially migratory.

Obs.--The Crested Lark is stated in the "Dublin Penny Journal," February 27, 1836, to have been killed near Taney, in the county of Dublin, but does not appear to have been satisfactorily identified.

* Alauda arborea (Linn.) Woodlark.

Very local and scarce, but is recorded as resident in small numbers in the counties of Antrim, Down, Armagh, Dublin, Waterford, and Cork (Thompson.) Wicklow (Watters.) Two specimens captured in winter, by Mr. W. Corbet, at Rathcormack, county Cork, have been presented to the Museum by Mr. A. G. More. Mr. Corbet remarks that he has only met with the Woodlark, when the ground is covered with snow. One was shot at the Tearaght Lighthouse, 20th October, 1887. (Migration Rep. for 1887).

\section{EMBerizide.}

Plectrophanes nivalis (Linn.) Snow Bunting.

Winter visitor, occurring regularly in the North, but rarely in the middle and South of Ireland.

Plectrophanes lapponicus (Linn.) Lapland Bunting.

Has once occurred. A female was picked up dead on the Fastnet Rock, county Cork, October 16th, 1887. (Zoologist, 1888, 1. 76, and Migration Report for 1887, p. 142.)

* mmberiza schoeniclus (Linn.) Reed Bunting.

Resident and common. More scattered in winter.

* Emberiza miliaria (Linn.) Bunting.

Resident; rather local, but widely distributed.

* mmberiza citrinella (Linn.) Yellow Bunting.

Resident and numerous. 
Bmberiza hortulana (Linn.) Ortolan.

Once obtained. The specimen now in the Museum and stated to have been taken in Clare, was exhibited by the late Mr. R. J. Montgomery before the Dublin Nat. Hist. Society, May, 1852. (Proceedings, Vol. i., p. 91.)

\section{Fringillidid.}

* Fringilla coelebs (Linn.) Chaffinch.

Resident and abundant. Often taken at Lighthouses when . migrating.

Fringlla montifringilla (Linn.) Brambling.

Irregular winter visitor, chiefly occurring in the North and middle of Ireland, and in hard weather. Several were taken in Waterford, 1887-8 (Mr. R.J. Ussher); also in Wexford in 1886 (Zoologist, 1889, p. 144.)

* Passer montanus (Linn.) Tree Sparrow.

Very rare, and hitherto found chiefly near Dublin, but apparently increasing of late years. Has occurred about Baldoyle, Sandymount, and Dalkey. Some nestlings, obtained by Mr. E. Williams from near Howth, are in the Museum. The first Irish specimen was exhibited in May, 1852, to the Dublin Nat. Hist. Society by Mr. R. J. Montgomery. A pair were found, as if breeding, on Arranmore Island, county Donegal, by Mr. H. M. Wallis, in May, 1886. (Zoologist, 1886, p. 489.)

* Passer domesticus (Linn.) House Sparrow. Resident and common.

Coccothraustes vulgaris (Pall.) Hawfinch.

Rare and irregular winter visitor. It has frequently occurred in the Phœnix Park, Dublin.

* Coccothraustes chloris (Linn.) Greenfinch. Resident and common.

* Carduelis elegans (Steph.) Goldfinch.

Resident, but local. Numerous in some parts of the South of Ireland.

* Carduelis spinus (Linn.) Siskin.

Occurs principally as a winter visitor, but the bird breeds freely in some parts of Wicklow and the nest has been found also in Antrim, Down, Wexford, and Waterford.

Linota linaria (Linn.) Mealy Redpoll.

Extremely rare winter visitor. One shot at Levitstown, Kildare, Feb. 9, 1876. (Newton's Yarrell, ii., p. 137.) 
Brambling- Ierm its cloee. Resemblance to the chafficich at a dielañes, il-isprobably oflen overeodeed in heland. hs lecher wiles in the desh Iportaman (30kí Jan 1892) halî-ocenro vory annler of

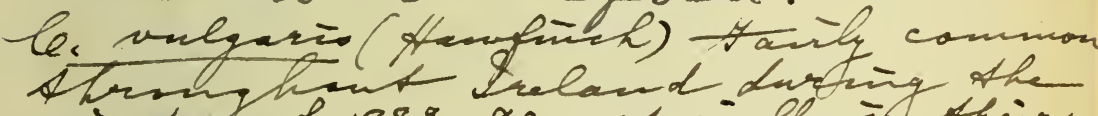

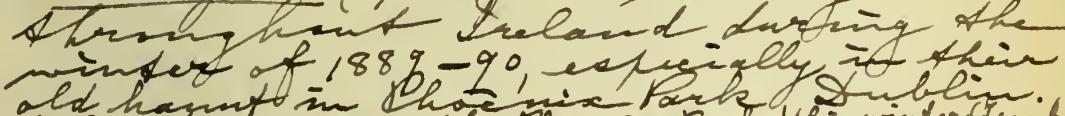

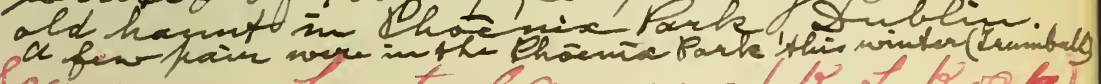
Seivins hortulanus (r. L kech) Serin. Has once accurred hrs 2. Willidms Recier d one from a huatio birsCateher 2 hd Vanuare, 1893

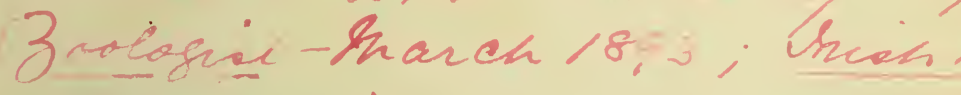
$189310.114)$

healy Redpole A omale flocts of abmi-right-remained during the winter of $1892-3$ on Aacile 
Co. Hayo, and one shot-in Haruary (1893) is kow is the hucseum (nish hal.-1893,1.114)

Parrol-Crosshil ve pityopsittacus hrttarl-wriles in the wieh hal$(1892,1.82)$ hul - he shot-a Cossbile' rear kiedery O. tongal ahne-tive year 1862 whian. he belins is have lism of finis varien. "Wll the lerose hills $\mathrm{mr}$. Willidins recesind in Ah winter of $1890-91$ wre of this variety 
*Inota rufescons (Vieill.) Lesser Redpoll.

Breeds in some parts numerously, but is better known as a winter visitor, often in company with the Siskin.

* Inota cannabina (Linn.) Linnet

Resident and common. Collects in large flocks in winter.

* Iinota flavirostris (Linn.) Twite.

Breeds, in many places, in the heathy and mountainous districts from the North to the South of Ireland. Mr. R.J. Ussher informs me that he has found the nest on the elevated coasts of Waterford as well as near the mountains.

* Pyrrhula europrea (Vieill.) Bullfinch.

Resident, and generally distributed in small numbers.

* Ioxia curvirostra (Linn.) Crossbill.

Rare and uncertain visitor. Has bred occasionally in the counties of Down, Wicklow, Meath, and Tipperary (Thompson). At Kilkea, Kildare. (Zoologist, 1868, p. 1133), and in Waterford (Zoologist, 1889, p. 180). The variety rubrifasciata has been obtained once at Edenderry, King's county. (Zoologist, 1889, p. 266.)

The Parrot Crossbill has occurred near Parsonstown (Zoologist, 1889 , p. 181), and has probably been passed over in other localities. Crossbills have been numerously seen in Ireland during the past few winters, and have remained during summer in many localities.

Loxia bifasciata (Brehm). Two-barred Crossbill.

Once obtained near Belfast, January, 1802. (Thompson). Another in 1868, in the county of Dublin. (Blake Knox, in Zoologist, 1868, p. 1376.)

\section{StuRNIDA.}

*Sturnus vulgaris (Linn.) Starling.

Resident and common. Large flocks arrive in autumn and winter, and are then seen flying south-west in Wicklow. During winter they collect in immense numbers at certain roosting-places.

Pastor roseus (Linn.) Rose-coloured Starling.

Rare and irregular visitor in summer and autumn.

\section{CoRvide.}

* Pyrrhocorax graculus (Linn.) Chough.

Resident in many places where the coast is rocky, and chiefly found in the West and South-west.

* Corvus corax (Linn.) Raven.

Rexident in small numbers, and docreasing. 
* Corvus corone (Linn.) Carrion Crow.

Extremely rare. A specimen from county Clare is in the Museum. Is recorded as found in the North, East, and West; also in Kilkenny and Tipperary. (Thompson.) The nest has been found near Belfast a few years ago ( $M r$. R. L. Patterson), and young birds evidently reared in the locality have this year been obtained from Mayo by Mr. H. B. Knox. Mr. B. Kane tells me that a carrion crow once mated with a hooded crow near Rostrevor, when five young were reared, and Mr. G. Esson describes the carrion crow as occasionally visiting the mountains in county Down in August and September. Mr. J. Anderson has found it breeding near Mourne Park.

* Corvus cornix (Linn.) Hooded Crow. Scald Crow.

Resident from North to South of Ireland.

*corvus frugilegus (Linn.) Rook.

Resident and numerous.

* Corvus monedula (Linn.) Jackdaw.

Resident and common.

* pica rustica (Scop.) Magpie.

Resident and now common. Was introduced from England previous to 1700 .

* Garrulus glandarius (Linn.) Jay.

Resident; but very local, occurring principally in the South and East of Ireland. Its head-quarters are in Kilkenny and Queer's county, extending to King's county, Kildare, Carlow, Wexford, Waterford, and Tipperary. Very rare, and only a straggler in Wicklow. Mr. E. Williams has noticed that the Irish jay is of a warmer and richer colour than the English bird.

\section{Hirundinide.}

* Hirundo rustica (Linn.) Swallow.

Regular summer visitor and numerous.

* Chelidon urbica (Linn.) House-Martin.

Regular summer visitor, less common than the Swallow.

* Cotile riparia (Linn.) Sand-Martin.

Regular summer visitor, and general, but not so numerous as the House-Martin.

Progne purpurea (Linn.) Purple Martin.

Native of America. Has once occurred. Near Kingstown probably in 1839. This specimen is now in the Musemm, and is the only authenticated example obtained in Europe. (Yarrell, Ed. 1, vol. ii., pp. 232* and 274.) 




\section{ORDER-PICARIA. \\ Cypselide.}

*Cypselus apus (Linn.) Swift.

Regular summer visitor. Rare in the West of Ireland. Once seen at the unusually late date of 4 th October, near Cappagh, Waterford. (Zoologist, 1887, p. 428).

Cypselus melba (Linn.) Alpine Swift.

Extremely rare visitor. Three examples are mentioned by Thompson, but no specimens have been obtained since. One shot at Rathfarnham, near Dublin, is in the Museum.

\section{Caprimulgide.}

- Caprimulgus ouropæus (Linn.) Nightjar.

Regular summer visitor, but local and rather rare.

\section{CUUCULID瓜.}

* Cuculus canorus (Linn.) Cuckoo.

Regular summer visitor, and generally distributed.

Coccystes glandarius (Linn.) Great Spotted Cuckoo.

Has once been obtained in Ireland; on the Island of Omey, Connemara, March, 1842. (Thompson.) The specimen is preserved in the Trinity College Museum.

Coccyzus americanus (Linn.) Yellow-billed Cuckoo.

Native of America. Has twice been obtained in Ireland, viz., in the counties of Cork and Wicklow. (Thompson.) The specimen from county Cork is in Trinity College Museum.

Coccyzus erythrophthalmus (Wils.) Black-billed Cuckoo.

Native of America. Has once been obtained in Ireland, viz., at Killead, co. Antrim, September 25th, 1871. (Zoologist, 1872, p. 3022, and Zool. Soc. Proc., 1872, p. 661.) Only one other instance is known of its occur: rence in Europe.

\section{UPUPIDE.}

Tpupa epops (Linn.) Hoopoe.

Rare visitor, in spring and autumn, but occurs nearly every year, and chiefly in the south of Ireland. Arrives sometimes very early-in March and even in February. 


\section{Coracirde.}

Coracias garrulus (Linn.) Roller.

Extremely rare and accidental visitor, chiefly in autumn. Has occurred eight or ten times in Ireland. Four are recorded by Thompson. One was shot at Ardrum, near Skibbereen, 29th October, 1883, as I am informed by Mr. W. Barrington. Mr. J. C. Neligan has a specimen which was shot at Corry, Co. Leitrim, in October, 1876. Mr. R. Warren tells me that one shot near Dunmanway, Cork, was in the collection of Dr. J. R. Harvey.

\section{Meropide.}

Merops apiaster (Linn.) Bee-eater.

Extremely rare visitor. Four are mentioned by Thompson, and one by Watters. A small flock of seven occurred at Trabulgan, Cork, in May, 1888. One of them is in the Museum. Another was obtained at Balbriggan, in May, 1889. (Zoologist, 1889, p. 229).

\section{AlCedinide.}

*Alcodo isplda (Linn.) Kingfisher.

Resident, but local ; occurring chiefly in the lowland districts.

ceryle alcyon (Linn.) Belted Kingfisher.

Native of America. Two individuals have occurred in Ireland, both in the autumn of 1845. (Thompson.) One obtained at Luggela, co. Wicklow, is in the Museum. The other, shot at Annsbrook, co. Meath, is in the Trinity College Museum. These are the only two which are known to have visited Europe.

\section{PicIder.}

Gecinus viridis (Linn.) Green Woodpecker.

Extremely rare and accidental visitor. Has occurred twice or perhaps three times in Ireland. One near Granard, co. Longford. (Thompson, Vol. iii., Appendix, p. 441.) Another at Sallymount, co. Kildare, 27th Sept., 1847. (Watters, p. 97.) A parrot-like bird reported to Mr. G. Barrett-Hamilton as having occurred at Fethard, Wexford, in June, 1888, was, in all probability, a green woodpecker (See Zoologist, 1889, p. 145).

Dendrocopus major (Linn.) Greater Spotted Woodpecker.

Very rare visitor ; but, of the three Woodpeckers, this is the most frequently met with in Ireland. Several were taken on, or near to, the east coast in the autumn of 1886 .

Jendrocopus minor (Linn.) Lesser Spotted Woodpecker.

Very rare visitor. Some six or seven specimens have been obtained. (Thompson, Appendix.) None recently. 


$$
\begin{aligned}
& \text { Mollen- Gor tabew nearin, } \\
& \text { lepternber 1591 ( } \\
& \text { Another on thurt Level Klob, } \\
& \text { Lorh havilly, leo. Donegal, }
\end{aligned}
$$

Bee-ealer Htas been oblained eighl-tines in heland. A female was ohrioñ - of a fivex poix near teegany, Cu. uccelow 1892 (Boologiel-he cember 1892 ; such hal - $1893,0.25)$

Geaimons viridio. A vary extensive the lafet moe kecabred during and the beginning of hoventer 1889, nhen bes mpleo mere tabeu from Womerach in (Gool. 1890, Gl. 24) 
Stock Drove, - is rapuidly exturding ito range in Encant. Oppured near Hallaghnoon, learlow,




Iynx torquilla (Linn.) Wryneck.

Has twice occurred. A specimen, killed near Dunmore, co. Waterford, 5th October, 1877, is in the Museum, having been kindly presented by Mr. Jacob who shot it. A second example was obtained at the Lighthouse on North Aran Island, Galway, on the 6th October, 1886 (Migration Report for 1886, p. 155).

\section{ORDER-COLUMBA.}

Columbide.

*Columba palumbus (Linn.) Wood-pigeon.-Ring-Dove.

Resident and common, becoming more abundant in winter.

* Columba cenas (Linn.) Stock Dove.

Very rare, and apparently only a recent settler in the northeast of Ireland, where it was first noticed in 1875, and has increased since that time, as I am informed by Mr. W. C. Stubbs. It has bred in county Down and at Ravensdale Park. (Zoologist, 1876, p. 4798, and 1877, p. 383.) Quite recently the nest has been found near Antrim, by the Rev. J. G. Holmes (Zoologist, 1889, p. 309) ; and Mr. J. Johnston informs me that two pairs have, this year, bred in the vicinity of Powerscourt Waterfall. Mr. H. Blake Knox has also obtained a specimen which was shot in Wicklow by his nephew in August, 1889.

* Columba ifvia (Gmel.) Rock Dove.

Resident, and not uncommon on the rocky coasts, especially in the West of Ireland.

* Turtur communis (Selby). Turtle Dove.

Rare summer visitor, but occurs probably every year in the South of Ireland. Has a few times nested in the counties of Down, Dublin, and Kerry.

Ectopistes migratorius (Linn.) Passenger Pigeon:

Native of America. Has once occurred near Tralee. (Thompson, Vol. iii., Appendix, p. 443.)

\section{ORDER-PTEROCLETES. \\ PTEROCLIDE.}

syrrhaptes paradozus (Pallas). Pallas's Sand-Grouse.

In June, 1863, a few small flocks visited Ireland and examples were obtained at Balbriggan, co. Dublin, Ross, co. Fermanagh, Drumbeg and Naran, co. Donegal. (Jhis, 1864, pp. 211 and 212. Zoologist, 1863, p. 8690.) The specimen shot at Drumbeg, Inver Bay, out of a flock of eight, is now in the Museum. On the 4 th of October, 1876, a male and female were shot near Kilcock, co. Kildare. (Field, Oct. 14, 1876.) 
A much larger immigration occurred in the spring of 1888 , of which Dr. R. F. Scharff, Curator of the Natural History Museum, has given a full account in the Scientific Proceedings of the Royal Dublin Society, Vol. vi. (N.S.), p. 278, from which it appears that the birds were widely scattered from north to south, and from east to west over Ireland, and Dr. Scharff estimates the number as possibly having exceeded many hundreds. A specimen from Tullamore, King's co., and another from Clare are in the Museum.

\section{ORDER-GALLIN A.}

\section{TetraONidE.}

- Iagopus scoticus (Lath.) Red Grouse.

Resident and generally distributed on mountains and bogs, but not so abundant as in the mountainous parts of Scotland. There is in the Museum a good specimen of the Albino variety. Hybrids between Grouse and Bantam were raised at Crumlin, near Dublin, by the late Mr. Hayes, as I an informed by my friend, Mr. A. R. Wallace, who has very kindly shown me several of the specimens.

Obs. - The Capercaillie, Tetrao urogallus (Linn.) was formerly an inhabitant of Ireland, but has long since been exterminated, having survived until about 1760 , or perhaps 1787 .

\section{Phasianide.}

- Phasianus colchicus (Linn.) Pheasant.

Well established, and breeds throughout Ireland, especially where protected. But is not a native bird.

* Perdir cinerea (Lath.) Partridge.

Resident and formerly more abundant than at present. Two specimens of the variety, which is called $P$. montana by Sir W. Jardine, are in the Museum.

* Coturnix communis (Bonn.) Quail.

A few breed regularly in the North-east, and occasionally in other parts of Ireland. Most of these remain throughout the winter, but the bird has very much decreased of late years.

\section{ORDER-FULICARIA.}

\section{RALLIDE.}

"Crex pratensis (Bechst.) Land Rail.-Corn-Crake.

Regular summer visitor. A few stragglers have occasionally been killed in winter. 

One of these hybrids is how hi
the ohuecenv, tisuderi. 
Bailens'Llates the specimen obtained al- Ir amor is now hi the husecin, Dublin. 
- Porzana maruetta (Leach). Spotted Orake.

Rare visitor, usually found in autumn. The nest has been found in Roscommon (Watters), and probably in Kerry (Thompson).

\section{Porzana parva (Scop.) - Little Crake.}

Has once occurred. At Balbriggan, 11th March, 1854. (Zoologist, 1854 , p. 4298.) The specimen reported by Mr. Reeves (Fowler in Ireland, p. 252) is, I understand, a
Spotted Crake.

\section{Porzana Bailloni (Vieillot). Baillon's Crake.}

Very rare. Only two specimens liave been obtained, viz. :-one near Youghal (Thompson), and one at Tramore, Waterford (Zoologist, 1882, p. 113), both of which I have examined. A supposed Baillon's Crake shot at Kanturk was very kindly shown to me by Mr. Longfield, and proved to be only
a Spotted Crake.

"Rallus aquaticus (Linn.) Water Rail.

Resident in small numbers throughout Ireland. Becomes more numerous in winter, and is often taken at the lighthouses when migrating in autumn.

\section{"Callinula chioropus (Linn.) Moor-Hen.-Water-Hen.}

Resident and common. A specimen of the hairy variety was obtained at Athlone in November, 1883. (J. H. Gurney, in Norfolk and Norwich. Nat. Hist. Trans. iii. p. 581).

Lobs.-Lord Ventry has very kindly allowed me to examine a specimen of the green-backed Porphyrio ( $P$. smaragnotus), in his possession, and which is labelled as having been obtained " in a cabbage garden near Odorney, on the river Brick, near Ballyheigue Bay, 10th October, 1873,"and Lord same species as the bird at Chute Hail, whis it is of the passed as the "Martinico Gallinule." Mr. J. has so long also tells me that there is an Irish specimen of another Porphyrio ( $P$. carruleus) in the collection of Mr. John Marshall, of Taunton, with neither date nor locality. But as neither of these Porphyrios has yet been admitted to rank fully as a British bird, I believe it best to exclude them for the present.]

rullca atra (Linn.) Coot.

Resident and frequent on lakes and large rushy pools. Migrates to the sea in hard weather. 


\section{ORDER-ALECTORIDES.}

\section{GRUIDE.}

Grus communis (Bechst.) Crane.

Very rare and accidental visitor. Two fine specimens in the Museum were presented by the Dublin Natural History Society, having been obtained in Kerry or Cork, in November, 1851, when a small flock of six or eight birds visited both counties. (Dublin Nat. Hist. Soc. Proc., i., p. 71). Thompson mentions one obtained in Galway and another in Kerry. In Seebohm's "British Birds" a male is recorded as shot in the co. Down, May, 1882, and Mr. R. J. Ussher records two in Mayo, one of which was killed, January 1st, 1884 (Zoologist, 1884, p. 72), and was by him very kindly presented to the Museum. Smith mentions that Cranes were seen in Waterford and Cork during the great frost of 1739. The name "Crane" is, by country people, commonly misapplied to the Heron.

\section{OTIDIDE.}

otis tetrax (Linn.) Little Bustard.

Sux Has times been obtained. One in Wicklow, 1833. (Thompson). One on the shore of Ballycotton Bay, 24th December, 1860. (Zoologist, 1861, p. 7385.) One shot near Belmullet, Mayo, in December, 1887, is recorded by Dr Scharff as recently added to the collection. (Zoologist, 1888, p. 108.) Another killed near Youghal, has very kindly been lent to the Museum by the owner, Mr. H. F. Allin. (Field, December 8, 1883. Zoologist, 1884, p. 69.) Obs.-Smith includes the Great Bustard among the Birds observed in Cork, but with no particulars; and as he gives also the Black Grouse in his list, no reliance can be placed upon either statement. (Antient and Present State of Cork, vol. ii., p. 329,--1750.)

\section{ORDER-LIMICOL无.}

CEDIUNEMIDE.

Gdionemus scolopar (S. G. Gmel.) Stone Curlew.

Very rare visitor in autumn and winter. Has occurred six or eight times in Ireland. A specimen from Tramore, Waterford, is in the Museum, from the collection of the Natural Hist. Society of Dublin. Another, obtained on the North Bull, Dublin, on the 3rd December, 1884, is also in the Museum. 
Litte Bustând. One shol-near Ballydufy, Co. Kerry $30 \mathrm{th}$ wee. 1892 (Wrish hal:-1893. p.56) a sich (female) was ehor-in Co tongford Frawary 1895-( Hich Mines hareh 2nd/895, Hich hat. $-1595,-10.105)$ 
Charadrius dommieus(P. L. S. Brile

relirginieus. American Yoiders)

Piover. ME 2 . Williams found one "am ongel- 2 of of bolelen Plovers, whieh kael blew ovidireci-ficin Belmulee, - Co Grayo" in the hublin market Zoologiel-1894, p.428; Sich rat: $\overline{1894}, \beta .22+$ )

Avocel:- One ohol- oul- of a bair al. Tingas kidely Co. Cork sth Yebuary 1895 ( Wish hal- 1895 o. 166) Cone inot at Weaford Aarbourlist 1895 th 319) 1895 - (9rich 


\section{Glareolida.}

Glareola pratincola (Linn.) Collared Pratincole.

Is believed to have once occurred. At Castlefreke, Cork, previous to 1843. (Harvey, "Fauna of Cork,") and (Thompson, Vol. ii., p. 81.)

\section{Charadritide.}

sudromias morinellus (Linn.) Dotterel.

Very rare and accidental visitor. One obtained in co. Donegal, and two shot on the hills near Clonmel, in September, 1886, are in the Museum.

" Esgialitis hiaticula (Linn.) Ringed Plover.

Resident; far more numerous in winter. Breeds on some of the inland lakes, as well as on the sea-shore.

Egialitis cantiana (Lath.) Kentish Plover.

Extremely rare visitor. One obtained on the North Bull, Dublin, is in the Museum.

"Charadrius pluvialis (Linn.) Golden Plover.

Breeds sparingly in most of the mountainous districts, and is much more numerous in autumn and winter.

squatarola holvetica (Linn.) Grey Plover.

Regular visitor in small numbers around the coast in autumn and winter, remaining till spring.

* Vanellus vulgaris (Bechst.) Lapwing.

Resident; but becomes much more numorous in autumn and winter.

Strepsilas interpres (Linn.) Tumstone.

Frequent on the coast, except in summer.

*ziæmatopus ostraiegus (Linn.) Oyster Catcher.

Conmon on the sea-coast, and breeds, but is more numerous in winter.

\section{SCOLOPACIDE.}

Recurvirostra avocetta (Linn.) Avocet.

Very rare visitor. A specimen, one of a pair first observed by Mr. R. Warren, was killed on the estuary of the river Moy, and presented to the Museum by Captain W. K, Dover. (Zoologist, 1877, p. 288.) 
Elmantopus candidus (Bonnat.) Black-winged Stilt.

Very rare visitor. Has occurred five or six times in Ireland. A specimen, killed at Ballinrobe, is in the Museum, from the Montgomery Collection. A pair were seen, and one of them shot, many years ago, near Kilbeggan, Westmeath, by the late Dr. R. Battersby.

Phalaropus fullcarius (Linn.) Grey Phalarope.

Rare and uncertain winter visitor. Several were taken in October and November, 1886. (Zoologist, 1887, p. 75.)

Obs. -The Red-necked Phalarope, which breeds in several parts of the West of Scotland, has not yet been found in Ireland, though it might well be expected to occur.

*scolopax rusticula (Linn.) Woodcock.

Numerous in winter. Many remain to breed, especially in the eastern and southern counties; and, as in Scotland, the bird appears to be extending its summer range. The birds reared in this country are believed to leave their breeding quarters in the early autumn.

Callinago major (Gmel.) Great Snipe.

Extremely rare and accidental visitor. Nearly all the so-called "solitary snipes" reported by sportsmen, are nothing more than large individuals of the Common Snipe. I know of only three Irish speeimens. One shot in Leitrim in October, 1886 (Zoologist, 1887, p. 75). One shot in Achill Island (Field, November 10, 1888), which Mr. R. Livesey has kindly shown to me; and a third, shot near Galway, October 12, 1888, has very kindly been presented to the Museum by Mr. W. H. Persse (Zoologist, 1889, p. 33).

*allinago coelestis (Frenzel). Common Snipe.

Breeds in small numbers throughout Ireland, becoming much more numerous in winter. The dark variety called Sabine's Snipe is execedingly rare, and has only been obtained somo Thuly-one fifteen times. (See Field, Dec. 10, 1870; Zoologist, 1884, 9. \%. $1895, / 0 / 3$ p. 272). One shot in Kildare, 5th December, 1886, and presented by Mr. G. M'Sheehy, and another obtained in the Dublin Market, 27th December, 1886, are in the Museum.

Gallnago gallinula (Linn.) Jack Snipe.

Regular winter visitor, much less numerous than the Common Snipe.

Limicola platyrhyncha (Temm.) Broad-billed Sandpiper.



Has once occurred. In Belfast Bay, 4th Oct., 1844. (Thompson.)

Tringa maculata (Vieill.) Pectoral Sandpiper.

Native of America. Has once occurred. In the Zoologist, 1889 , p. 32. Mr. E. Williams has recorded a specimen obtained near Portumna in October, 1888, which Dr. Scharff informs me is now in the Museum. 


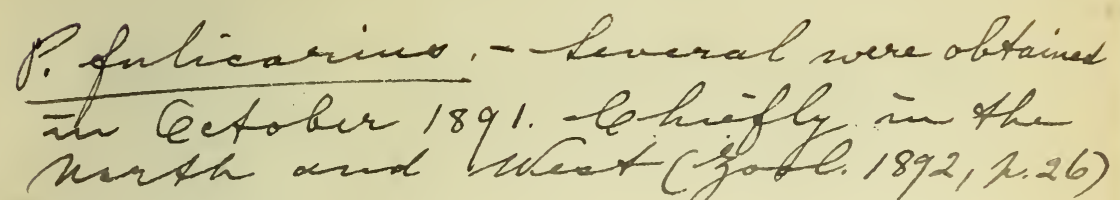

Phalarofus hiperboreus plivin)

Red-neeteed Shalarofe. Onec obtained. At dough bìn, Co.

Armagh, Govember 18q't' Li -i

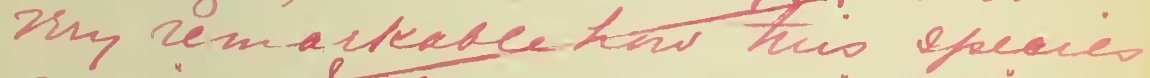
avoids beland on mighation Toologisl-1892,15.28; mich hat: $1892,10.4)$

Greal-Sifer. Has ocenced four times. une lase- epecinew was onv-ly his. I. In acon al - Ballesoy C. Inayo 13 h ocl: 1893 (rich hal 1893, s. 302 )

Hacrorh amphus Eriseus (\$. I Gnel) Red-breasted \&rifAtas tivice occureo. A Kemal, Ohol- xi-hary hrough, Queenó Co. Neplember 1893 is in the of $B$ irmingh an oblained of ammina a Col of Diipe reciero This sperinien uras aubrequently

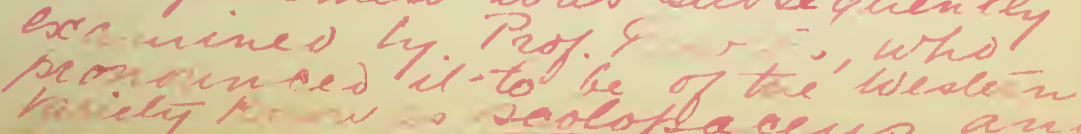



Onsin sial. 1593,10.323)

Bartramó Sandpiper A reoond ecauple was ohol-al-kewces-

- Lown, Co. Cork 4 th Replember 1894 (rich hal -1895, 166 ) 
Tringa fuscicollis (Vieill.) Bonaparte's Sandpiper.

Native of America. Is believed to have once occurred. A specimen in the Belfast Museum is supposed to have been shot in Belfast Bay. (Thompson, Vol. ii., p. 297.)

"Tringa alpina (Linn.) Dunlin.

Abundant on the sea-shore except in summer. A few breed on the bogs and moors in the West and North of Ireland.

Tringa minuta (Leisler). Little Stint.

Regular autumnal visitor, but in very small numbers, and chiefly along the North-east coast.

Tringa Temminckii (Leisler). Temminck's Stint.

Has once occurred. Near Tralee at the unusual date of January, in 1848. (Thompson, Vol. ii., p. 302).

Tringa subarquata (Guldenst.) Curlew Sandpiper.

Regular autumnal visitor in small numbers-very rare in winter.

Tringa striata (Linn.) Purple Sandpiper.

Regular visitor in autumn and winter, but not numerous.

Tringa canutus (Linn.) Knot.

Frequent on the sea-shores in autumn and winter.

Colldris arenaria (Linn.) Sanderling.

Regular visitor in autumn and winter.

rachetes pugnax (Tinn.) Ruff.

Rare visitor, chiefly in autumn.

Tryngites rufoscens (Vieill.) Buff-breasted Sandpiper.

Native of America. Has twice occurred. The specimen shot near the Pigeon House, Dublin (Thompson, Vol. ii., p. 302), is in the Museum, having been presented by the Natural -History Society of Dublin. Two were shot at the People's Park, Belfast, October, 1864. (Zoologist, 1866, p. 389.)

Bartramia longicauda (Bechst.) Bartram's Sandpiper.

Native of America. Has occurred. A specimen having been obtained by Mr. Joseph Dunn, in 1855, among other wild fowl sent to him from Ballinasloe.

"Totanus hypoleucus (Linn.) Common Sandpiper.

Regular summer visitor, and breeds from North to South of Ireland.

Totanus ochropus (Linn.) Green Sandpiper.

Rare visitor, occurring chiefly in autumn. 
rotanus glareala (Gmel.) Wood Sandpiper.

Has once occurred. One was shot on Calary Bog, near the Sugar-loaf Mountain, Wicklow, 23rd August, 1885, and was presented to the Museum by the Rev. Dr. Benson (Zoologist, 1885, p. 438).

"rotanus calldris (Linn.) Common Redshank.

A few breed on the inland marshes and lakes, becoming numerous on the sea-shores in autumn and winter.

rotanus fuscus (Linn.) Spotted Redshank.

Very rare visitor, chiefly in autumn. Single birds have several times been observed and twice shot by Mr. R. Warren on the estuary of the Moy. The specimen in the Museum was obtained by Mr. Williams, from Sallins, Co. Kildare (Zoologist, 1887, p. 75).

Totanus canescens (Gmel.) Greenshank.

Regular visitor in autumn, remaining all through winter and spring.

Imosa ægocephala (Linn.) Black-tailed Godwit.

Rare visitor, chiefly in autumn.

Iimosa Iapponica (Linn.) Bar-tailed Godwit.

Regular visitor in autumn, a few remaining through the winter; and the bird is most numerous in spring.

* soumenius arquara (Linn.) Curlew.

A few breed on the bogs and moors. Plentiful on the coast in autumn and winter.

sumenius phreopus (Linn.) Whimbrel. "May-bird."

A passing visitor to the sea-shores in spring and autumn.

wumenius boreais (J. R. Forst.) Eskimo Curlew.

Native of America. Has once occurred. Obtained in a poulterer's shop in William-street, Dublin, and said to have been shot in Sligo, October, 1870. (Zoologist, 1870, p. 2108.) This specimen has been very kindly presented to the Museum by Sir Victor Brooke.

\section{ORDER-GAVIAE.}

\section{LARIDE.}

Eydrochelidon nigra (Linn.) Black Tern.

Rare visitor, chiefly in autumn, has occurred also in spring. I have seen an immature bird which was obtained by Mr. J. R. Sheridan in Achill Island, in September, 1887. 
Spolted Redahante- Hs 2 villiang who oblained two on the coadofhualin becives illowe nueh commoner than is usualey hoppoded (Mich kal$1894 p .224$ ) Lewer have hew take in Swlandi four or

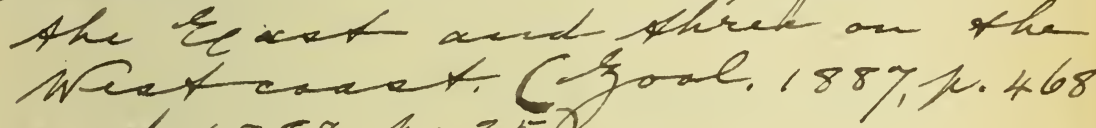
and $1859,12.33=9$ 
While winged Black Yern. Anothe oflained Rear hewhactecl: on Hergus, Co. Clare 1893 is aled is the museum bualin (Sich hat$1893,(0.25-3)$

Gull-biled Yern. Hs A. I. hore sabrequently excamined ticis Hecimen and found it. to be an inmalie Arcice Kerw (uin hal: 1892,p.4) 
Ifydrochelidon leucoptera (Schinz). White-winged Black Tern.

Has times occurred. One shot at Cappagh, Waterford, 13th May, 1875, was presented to the Museum by Mr. R. J. Ussher.

IIydrochelldon hybrida (Pallas). Whiskered Tern.

Has once occurred. (Thompson). This specimen, shot in Dublin Bay, in September, 1839, is in the Museum, from the collection of the late Mr. T. W. Warren.

Sterronalica (Mont.) Gull-billed Tern.

Has once occurret. Belfast Lough, towards the end of Sentember, 1887, is recorted-by Professor R. O., etinningham (Zoologist, 1887, p. 433).

* Sterna cantiaca (Gmelin). Sandwich Tern.

Regular summer visitor, but rare and very local.

*sterna Dougalli (Montagu). Roseate Tern.

Very rare summer visitor, breeding in a very few localities, and has become much more scarce of late years.

* sterna fiuvlatius (Naum.) Common Tern.

Regular summer visitor, breeding on lakes and shores.

* Sterna macrura (Naum.) Arctic Tern.

Regular summer visitor, and with the former the most common species of Tern. Breeds on freshwater on Lough Carra, Mayo.

* Sterna minuta (Linn.) Lesser Tern.

Regular summer visitor, breeding on various parts of the coast.

Anous stolldus (Linn.) Noddy Tern.

Native of America. Has once occurred. Two were shot off the Tuskar Lighthouse, Wexfurd, in summer about 1830 (Thompson). One of these, from the Warren Collection, is in the Museum. The only occurrence in Europe.

xema Sabinel (J. Sabine). Sabine's Gull.

Native of America. Rare and accidental visitor in autumn, when it occurs in immature plumage. Some ten or twelve have at various times been obtained. Three are in the Museum.

Larus philadelphia (Ord). Bonaparte's Gull.

Native of America. Has once occurred. One shot on the Lagan, near Belfast, 1st February, 1848. (Thompson.) Two "less thoroughly authenticated" instances are also on record. (Zoologist, 1855, p. 4762, and Zoologist, 1866, p. 306.) (Nat. Hist, Review, 1855, pp. 65 and 95.) 
Iarus minutas (Pallas). Little Gull.

Very rare and uncertain visitor in autumn and winter.

- Iarus ridibandus (Linn.) Black-headed Gull.

Resident, and breeds on marshes and on islands in freshwater lakes, from North to South of Ireland. The so-called Masked Gull is now generally admitted to be a mere variety. A very large colony breeds on a bog near Tullamore, in King's co. (Zoologist, 1889, p. 396).

- Iarus canas (Linn.) Common Gull.

Common in winter. A few remain to breed both inland and on the sea-coast, chiefly in the West of Ireland, viz., in the counties of Kerry, Mayo, Sligo?, Donegal.

- Larus argentatus (Gmel.) Herring Gull.

Resident and common. Breeds all round the coast.

* Irarus fuscus (Linn.) Lesser Black-backed Gull.

Resident. Breeds in small numbers on lakes and more numerously on various parts of the coast.

"Iarus marinus (Linn.) Great Black-backed Gull.

Resident. Breeds on the sea-coast in small numbers; becomes more numerous in winter.

Iarus glaucus (O. Fabricius.) Glaucous Gull.

Rare and uncertain winter visitor.

Iarus Iencopterus (Faber.) Iceland Gull.

Very rare and accidental visitor in winter.

- ressa tridactyla (Linn.) Kittiwake Gull.

Resident and breeds abundantly round the coasts. Many remain all winter.

Pagophila eburnea (Phipps). Ivory Gull.

Extremely rare and accidental visitor. Two examples have been obtained and others observed (Thompson). Mr. R. Warren now believes a mistake was made as to the bird seen 21st September, 1862, near Moyview in Sligo. (Dubl. Nat. Hist. Soc. Proceedings, iv., p. 62.) An Ivory Gull, belonging to the late Dr. J. R. Harvey's collection, now in Queen's College, Cork, was obtained, as Mr. Warren informs me, in Bantry Bay.

stercorarius catarrhactes (Linn.) Great Skua.

Very rare visitor, chiefly in autumn. One recently obtained in Dublin Bay is in the Museum.

stercorarius pomatorhinus (Temminck). Pomatorhine Skua.

Regular autumnal visitor in varying numbers, usually seen in October. 

Ereal- Shearualer. Int PobentWarren mentions (Zoologiel Dan. 1894) having seew on 2 snd Aferi 1893 -elen sreal- Ohearualiro al-innis crone, E. mayo. Ate Aggeds that - they may, possialy breed on the rish coase.

Wustey Shearualei- Whis specmin was inose-liberally precentev to the Busenon hy hus Bewicke Bladehurw.

Oceanites oceanicus (ruth) ivileonis. Petrel. Has tivice or three times oceurred. One beliecrel to Hat ren oblained in \& Wublin was given to Thombson in, augud 1840 (Atoward Saunders manual Y

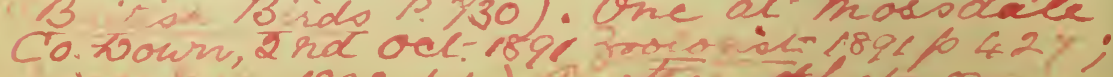


Btorcorarfus crepldatus (Glm.) Richardson's Skua.

Regular visitor in autumn. Has occurred also, less frequently, in spring.

stercorarlus parasiticus (Linn.) Buffon's Skua.

Autumnal visitor in small numbers and less frequent than Richardson's. Has also occurred in spring.

\section{ORDER-TUBINARES.}

\section{Procellaridde.}

Fulmarus glaclalis (Linn.) Fulmar Petrel.

Rare and accidental visitor in autumn and winter. It has several times been washed ashore dead in the estuary of the Moy. Three birds, thus picked up by Mr. Robert Warren, are in the Museum. One was obtained in Rathlin Island, 2nd September, 1889. (Ibis., 1889, p. 580.)

Puminus major (F. Faber). Great Shearwater.

Rare and uncertain visitor, chiefly in autumn, and on the West coast. The evidence in favour of its breeding in Ireland (Fowler in Ireland, p. 289) seems quite insufficient.

Puffinus griseus (Gmel.) Sooty Shearwater.

Very rare and accidental visitor. A specimen, obtained off the coast of Kerry, is in Mr. Chute's collection. (Zoologist, 1881, p. 334.) The hird is also believed to have been observed by Mr. R. Warren, off Cork Harbour, in Angust, 1849. (Zoologist, 1881, p. 420.) Mr. R. Lloyd Patterson has one which was shot on Belfast Lough, 29th September, 1869.

*Pufinus anglorum (Temminck). Manx Shearwater.

Occurs chiefly as a summer visitor, and in autumn. Breeds on islands off various parts of the coast.

Puffinus obscurus (Gmel.) Dusky Shearwater.

Has once occurred off Valentia, 11th May, 1853. (Watters, p. 268.) (Yarrell, "British Birds," Ed. 3, Vol. iii., p. 659.)

* Cymochorea leucorrhoa (Vieill.) Fork-tailed Petrel.

Known chiefly as a rare and accidental visitor. But Mr. R. J. Ussher has recently obtained eggs from the Blasquet Islands, and from the Great Skellig, both in Kerry. (Zoologist, 1887, p. 349.)

- Procellarla pelagica (Linn.) Storm Petrel.

Breeds in considerable numbers on several of the islands off the West and North coasts, and is frequently picked up inland after stormy weather. 


\section{ORDER-PYGOPODES.}

\section{AlCID F.}

* Alca torda (Linn.) Razor-Bill.

Breeds in large numbers on rocky parts of the coast. A few remains throughout the winter.

Alca impennis (Linn.) Great Auk.

Has once occurred; near Waterford, May, 1834. (Thompson.) This specimen, which came into the possession of Dr. Burkitt, is in the Trinity College Museum.

* tria trolle (Lini.) Common. Guillemot.

Breeds on the cliffs all round Ireland. A few remain in winter. The Ringed Guillemot, now considered a mere variety, occurs in small numbers associated with the type.

*uria grylle (Linn.) Black Guillemot.

Breeds locally in small numbers all round the rocky coast, and remains all the year.

acergulus alle (Linn.) Little Auk.

Rare and uncertain winter visitor.

* Fratercula arctica (Linn.) Puffin.

Summer visitor. Breeds on the rocky coasts all round Ireland. A few are rarely found in winter. A white variety is in the Museum.

\section{Colymbide.}

Colymbus glacialis (Linn.) Great Northern Diver.

Regular winter visitor. A few birds in adult plumage occasionally occur quite late in spring.

Colymbus arcticus (Linn.) Black-throated Diver.

Rare visitor in winter. Seen also on its northward migration late in spring.

* Colymbus septentrionalis (Linn.) Red-throated Diver.

Regular winter visitor, and, like the former, often found late in spring. The nest has been more than once found in Donegal. (Field, 30th May, 1885).

\section{PODICIPITIDAE}

*Podiceps cristatus (Linn). Great Crested Grebe.

Breeds on several of the lakes in the North of Ireland; but is more numerous as a winter visitor, on fresh, and rarely, salt water. 


\section{THE GREAT AUK (ALCA IMPENNIS) AS AN IRISH BIRD.}

BY G. E. H. BARRETT-HAMILTON, B.A.

So little is known of the past occurrences or status in Ireland of the Great Auk, that I think no apology is needed for bringing to the notice of readers of the Irish Naturalist the statement of Mr. W. J. Knowles in his " Third Report on the Pre-historic Remains from the Sandhills of the Coasts of Ireland" that he had obtained on the Antrim coast bones which had been identified by Mr. E. T. Newton, of the Geological Survey, as those of the Great Auk. These bones were obtained in the sandhills of Whitepark Bay, Co. Antrim, in conjunction with human remains which Mr. Knowles believes to be those of the earliest Neolithic inhabitants of Ireland. In accumulations of the same age were found bones of the Horse, and of the Dog or Wolf (whether wild or domesticated is uncertain), as well as remains of geese, ducks, and gulls. Mr. Knowles remarks that "from the number of bones [of the Great Auk] which have been found, it must have been a common inhabitant of the North of Ireland at the time when the people of the Stone Age occupied Whitepark Bay and other parts of the coast." In a previous paper ${ }^{2} \mathrm{Mr}$. Knowles recorded the finding, in the same locality, of two humeri of the Great Auk, besides bones of Bos longifrons, Cervus elaphus, Sheep or Goat, Fox, Pig, a small goose, a small gull, and cod. This statement is of such great interest, not only to Irish ornithologists, but to ornithologists in general, that it is a pity that it should be hidden away in a paper which deals with a subject other than natural history.

The only localities given by Professor Newton ${ }^{3}$ where bones of the Great Auk have been found are in the kitchen-middens of Denmark, and in similar deposits in Caithness and Oronsay, and in a cave on the coast of Durham. The Irish locality, therefore, makes an interesting addition to our knowledge of the distribution of this bird in past times. Mr. Knowles points out that the "old surfaces of the sandhills, with their shells, broken bones, and implements, are really kitcheli-

\footnotetext{
Proc. R.I.A. (3), vol. iii., No. 4, pp: 650-663 (Dec., I895).

"Proc. R.I.A. (3), vol. i., No. 5 (1891).

3 "Dictionary of Birds," article "Extermination," p. 220.
} 
middens, and of the same nature as those of the continent, e.g., in Portugal, and also at various parts along the coast of France, as well as in Denmark. The fauna of the sandhills is wonderfully in line with that of the kitchen-middens of Denmark, and the finding of the Great Auk, which is now extinct in Europe, among the Irish remains, makes the likeness more complete."

As regards the occurrence of this bird on the Irish coasts in modern times, the last authenticated British example ${ }^{x}$, and the last but two which is known to have lived, was taken alive near the entrance of Waterford Harbour, in May, I834, by a fisherman named Kirby. It was kept alive for some little time by Mr. Jacob Gough of Horetown, in Co. Wexford, but eventually came into the hands of Dr. Burkitt of Waterford, and it is now in the museum of Trinity College, Dublin. The details of the capture of this bird, and of its subsequent history, as given by Thompson ${ }^{2}$, appear to have been somewhat inaccurate, and have been corrected by Mr. J. H. Gurney, jun., on the authority of Dr. Burkitt. It was afterwards ascertained by Mr. Davies that a second specimen was procured on the Waterford coast at about the same time, but was not preserved.

Besides the above, details of three other occurrences are given by Thompson ${ }^{4}$, but in no case was a specimen forthcoming. One of these specimens was stated, in a note communicated by Rev. Joseph Stopford, in February, I844, to Dr. Harvey of Cork, no date being mentioned, to have been " ob. tained on the long strand of Castle Freke (in the west of the County of Cork) ; having been water-soaked in a storm." In the other case Thompson believed that two birds described to him by H. Bell, a wild-fowl shooter, as having been seen in Belfast Bay, on September 23rd, I845, were of this species.5

'Newton, Op. cil., p. 220.

2 Proc. Zool. Soc., Lond., I835, p. 79; and "Nat. Hist. of Ireland," III., p. 23 S.

3 Zoologist, r868, pp. I449-1453.

- Op. cit., p. 239; Zoologist, I868, pp. I442-I453; I869, pp. I039-IO43.

5 The statement in Sampson's "Survey of Londonderry" (I802) that the Alca Impennis, Penguin, "frequents the rocks of that county and of Donegal," evidently refers to the Razorbill, which bird is not mentioned in his list. It is curious tliat Dr. Pocock describes " the Razorbill or Auk, as big as a Pheasant, witl a parrot bill," as breeding at Horu Head in 1752-vide Dr. Stokes' edition of Pocock's “'Tour in Ireland in I752," p. 59. 
Lite Acute- Hour recorded in the wiles is 1893- one ar hie holst and the ce in the west:

I 


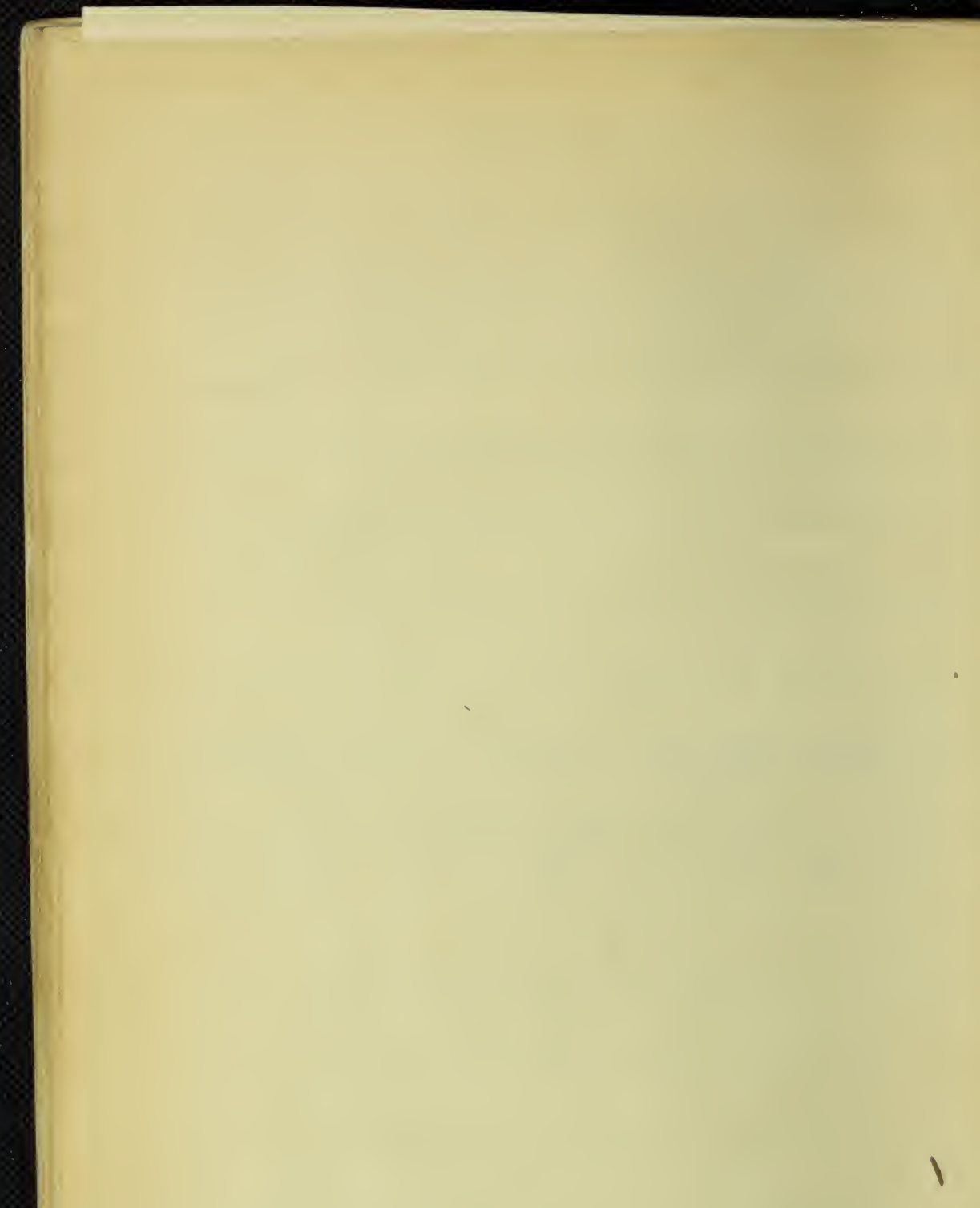


Podiceps griselgena (Boddaert). Red-necked Grebe.

Very rare and accidental winter visitor, chiefly found on salt water. Only five or six specimens have been obtained in Ireland. One shot many years ago in Inver Bay, Donegal, is in the Museum.

Podiceps auritus (Linn.) Sclavonian Grebe.

Regular winter visitor, in small numbers. Usually found on salt water.

Podiceps nigxicollis (C. L. Brehm). Eared Grebe.

Very rare and accidental visitor, chiefly on salt water, in winter, but has twice occurred, in full summer plumage, in June.

*Podiceps Inviatils (Tunstall). Little Grebe.

Resident and common. Often found on the sea in winter.

\section{ORDER-STEGANOPODES.}

\section{Pelecanide.}

* Phalacrocorax carbo (Linn.) Common Cormorant.

Resident and common. Fishes on freshwater far inland, and occasionally breeds on islands in freshwater lakes. As inland nesting localities may be mentioned Lough Outra, Lord Gough's seat in Galway, where Lord Gough tells me that from eighty to one hundred birds breed annually. The cormorant has also been found nesting on a few small lakes in Connemara, and in Mayo.

* Phalacrocorax graculus (Linn.) Shag.

Resident, especially abundant on the north-west coast.

* sula bassana (Linn). Gannet.

Breeds on the Little Skellig, co. Kerry, and on the Bull Rock, co. Cork. Not on the Eastnet Rock (Zoologist, 1884, pp. 474 and 479.)

\section{ORDER-HFRODIONES.}

\section{ARDEIde.}

* Ardea cinerea (Linn.) Common Heron.

Resident, and common throughout Ireland. A fawn-coloured variety is in the Museum. Generally known as "Crane." Breeds sometimes on sea-cliffs, as in the Dingle Peninsula, and formerly in Waterford $(M r . R$. J. Ussher). Also on the ground, as on Garumna Island, Galway (Mr. G. H. Kinahan). 
Ardea purpurea (Linn.) Purple Heron.

Has once occurred; at Carrickmacross, Monaghan, previous to 1834. (Thompson.) This specimen, which belonged to the collection of Mr. T. W. Warren, is in the Museum.

Ardea garzetta (Linn.) Little Egret.

Extremely rare and accidental visitor. It is recorded as having occurred three times (Thompson), but no Irish specimen is in existence.

Ardea ralloldes (Scopoli). Squacco Heron.

Extremely rare visitor. Has occurred four or five times in spring or early summer in the South of Ireland. A specimen shot at Youghal, co. Cork, is in the Museum.

sycticorax grisous (Linn.) Night Heron. Lêrelve or fourleén

Very rare and accidental visitor. Has occurred ten or twolve times in Ireland. A specimen obtained in county of Louth is in the Museum. An immature bird was shot at Rathgar quarries, 31st December, 1888 (Zoologist, 1889, p. 110).

Ardetta minuta (Linn.) Little Bittern.

Very rare visitor. Has occurred about ten or twelve times in Ireland. A specimen, shot at Skerries, co. Dublin, is in the Museum. Another shot in Wexford, October 2nd, 1887 (Zoologist, 1889, p. 145), is, as Dr. Scharff informs $\mathrm{me}$, also in the Museum.

Botaurus stellaris (Linn.) Bittern.

Rare and irregular winter visitor, but occurs nearly every year. Recorded as formerly breeding in a few localities, but the nest has not been found for many years past.

Botaurus lentiglnosus (Mont.) American Bittern.

Native of America. Extremely rare visitor. Has occurred fix times in Ireland, viz., in the counties of Armagh (Thompson), Down, Louth, Tipperary, and Cork, in the months of October and November. A specimen shot at Castlering, Louth, November, 1868, was presented to the Museum by Lord Clermont.

\section{Ciconime}

Ciconia alba (Bechst.) White Stork.

Has twice been obtained. Near Fermoy, co. Cork, in 1816 (Thompson), and on Hop Island, on the river Lee, co. Cork, 7th August, 1866. (Zoologist, 1866, p. 524.) 
Lquacetteron. Lent atuinar


hight-Steron. Anohin hecur


$1893.16 .324)$

Letted Bitterar one shor- on the Barrón al-Carew 19kithay(:) 1895- (Land Khatén Sune 1st-1895)

Billen Ohe uconded in 1892 one ii 1893 one hi 1894

Ameriean Bittern- Another sholAt Haddialioñ Bog, Co. Kiedare is aleo in the Hureum. Gne ohat on Bally rowan Mnocs near magniaplet, Lowdondery, Gedtober $188 \%$ (Gool. ñne tin (Irombiel) The mith, a female, wmo Nogt teo. Hild are, 20 th thetracy 189 ( cool. 1891, p.218) 
Ancer brachyru rahus (Baile) Pink-footéo Goose. The piver-lrion Sterime was shot on tough builly Co. Nonegal, Oclober 1891 ( Joon is: $18,5$, p. 33; sisu rat: $1892 \% .4)$ 


\section{IBIDIDE.}

Plegadls falclnellus (Linn). Glossy Ibis.

Rare and uncertain visitor, chiefly in autumn and early winter.

One specimen from Longford, and three presented by the Dublin Natural History Society, are in the Museum.

\section{Plataleide.}

Platalea leucorodia (Linn.) Spoonbill.

Rare and irregrular visitor, occurring on the coast, chiefly in autumn and winter. Two specimens in the Museum formerly in the collection of the Dublin Natural History Society), were obtained on the estuary of the Bandon River, Oork, in December, 1860.

\section{ORDER-ANSERES.}

ANatides.

Respecting the Birds of this family much interesting information will be found in Sir R. Payne-Gallwey's Book, "The Fowler in Ireland." London, 1882.

\section{Anser clnereus (Meyer). Grey-Lag Goose.}

Regular winter visitor, but local and rare, occurring chiefly inland, and in the centre and east of Ireland. There is a colony of semi-domesticated birds breeding regularly on a lake at Oastlecoole, co. Fermanagh (Thompson). The Bog of Allen and a bog near Kirkiston, co. Down, are mentioned as former breeding-places. A large flock frequents, during winter, some fields near the Murrough of Wicklow, remaining till late in spring, but not through the summer. (See Fowler in Ireland, p. 154.)

\section{anser albifrous (Scop.) White-fronted Goose.}

Regular winter visitor, and not uncommon inland, as well as on salt water. The commonest of the Grey Geese in Ireland.

Anser segetum (Gmel.) Bean Goose.

Regular winter visitor, generally distributed, but much less frequent than the White-fronted Goose, and seldom seen in the Dublin markets.

Obs. - The Pink-footed Goose is believed to have been recog. nized by Sir Victor Brooke who writes that-About ten or twelve years ago he distinctly identified, with a telescope, a pair of Pink-footed Geese amongst a large flock of Grey-lags, feeding in some marshy fields in Meath, and adds that "to an experienced eye a pink foot is very easily distinguished on the ground." The Pink-footed Goose occurred numerously in 1884, on the opposite coast of Lan. cashire, but no specimen has yet been obtained in Ireland. 
Chen hyperboreus (Pallas). Snow Goose.

Native of America. Has three times occurred. Two were shot at Tacumshin Lake, in November, 1871, another subsequently in Wexford Harbour. (Howard Saunders, in Zool. Soc. Proceedings, 1872, p. 519.) In October, 1877 , a flock of seven birds were seen at Termoncarra, near Belmullet, Majo, of which two were captured. (Zoologist, 1878 , p. 419). One of these lived, associated with, and paired with some domestic geese until the spring of 1884 , when it was unfortunately killed by a stone. This specimen has been most liberally presented to the Museum by Mr. J. R. Crampton. Mr. H. Blake Knox informs me that about 1st October, 1886, he received a fine male Snow Goose, which had been shot by one of his tenants, near Belmullet, Mayo.

Obs.-The Egyptian Goose has occasionally been shot on the coast, but cannot be considered a wild bird.

Bernicla leucopsis (Bechst.) Barnacle Goose.

Regular winter visitor, but local and rare except at Lurgan, Dundalk, Sligo, Achill, Erris, and Clew Bay.

Obs.-The Canada Goose has occasionally been shot in an apparently wild condition. No doubt escaped from domestication.

Bernicla brenta (Pallas.) Brent Goose.

Regular winter visitor, occurring locally on the muddy estuaries all round the coast.

Cygnus musicus (Bechst.) Whooper Swan.

Winter visitor, rare. Occurring chiefly in hard winters.

Cygnus Bewicki (Yarrell.) Bewick's Swan.

Winter visitor; frequent, especially in hard weather, and much more numerous and occurs in larger flocks than the Whooper.

[*ygnus olor (Gmel.) Mute Swan.

Introduced, but breeds regularly "on many of the un. protected lakes and rivers of Ireland." Sir R. PayneGallwey records the occurrence in 1881, of three Polish Swans, and Mr. J. R. Sheridan has obtained what he believes to be the Polish Swan, in Achill Island, but I do not know how this supposed species can be satisfactorily distinguished from immature birds of the Muto Swan.] 

Riddy Sheedrater-Several smale floctes were Recorded from Varions parto op helend during Suly and Augual-1892

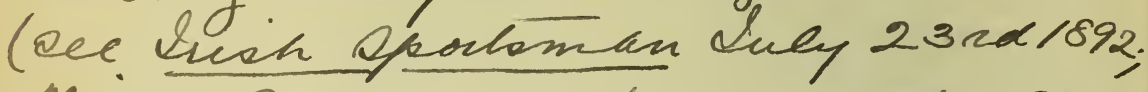
Heed Angusl-20 in and 2ym-1892; Joologice. Seplember 1892; Sush hal:- $1892,0.14 \%)$ 
Tadorna casarca (Linn.) Ruddy Sheldrake.

Has several times occurred, but some of the birds may lave escaped from domestication. One shot on the Murrough of Wicklow (Thompson), is in the Museum from the collection of the late Mr. T. Warren. Another shot about March 20th, 1871, on Clonea Marsh, co. Waterford, was presented to the Museum by Mr. W. W. M'Guire. A third shot near Tralee, 17th August, 1869, is in the collection of Mr. J. C. Neligan. (Zoologist, 1870, p. 2105.) A fourth, in the Museum at Trinity College (Fowler in 1reland, p. 66), was mounted from a dried skin, and was, in all probability, of foreign origin. Several occurred in Cork, and on the Shannon, in June and July, 1886. (Zoologist, 1886 , p. 335 , and 1887, p. 25.)

* Tadorna cornuta (Gmel.) Common Sheldrake.

Breeds sparingly on the sand hills round the coast. Becomes more numerous in winter.

* Anas boscas (Linn.) Wild Duck.

Breeds in small numbers throughout Treland, and becomes much more numerous in winter.

Chaulelasmus streperus (Linn.) Gadwall.

Rare winter visitor occurring from North to South of Ireland.

* Spatula cigpeata (Linn.) Shoveller.

Regular winter visitor in small numbers. A few breed in several parts of Ireland-Dublin, Queen's Co., Galway, \&c. An adult male in the brown summer plumage, killed with two young ones at Baldoyle, on the 24th July, 1876, was presented to the Museum by Mr. J. J. Dowling.

* Dafla acuta (Linn.) Pintail.

Regular winter visitor, but not numerous. Sir R. Payne-Gallwey mentions that one or two pair breed every year at Abbeyleix, Queen's county, and records having himself observed female Pintails with young broods in June, both on Lough Mask and Lough Corrib, co. Galway. (Fowler in Ireland, p. 51.)

* Querquedula crocea (Linn.) Common Teal.

Breeds in various parts of Ireland, and is numerous in winter.

Querquedula circla (Linn.) Garganey.

Very rare visitor, chiefly in spring, but has occurred also in winter. One shot on the River Barrow in March, 1888, Dr. Scharff informs me, is in the Museum, and another was obtained in April, 1888, near Dublin. (Zoologist, 1888, p. 187.) 
* Mareca penelope (Linn.) Wigeon.

Common winter visitor. A few pairs remain to breed in the counties of Antrim, Armagh, Tyrone, Mayo, and probably on the Lakes of the Shannon. I am indebted to Lord Castletown for the information that one pair of Wigeon bred at Abbeyleix in 1888.

Fuligula rufina (Pallas). Red-crested Pochard.

Has once occurred; having been obtained by Sir R. PayneGallwey from a fowler who shot it near Tralee, January 18th, 1881. (Zoological Society of London Proceedings, 1881, p. 409, and Zoologist, 1881, p. 143.)

* ruliguia ferina (Linn.) Pochard.

Regular winter visitor, both on fresh and salt water. Has nested near Strangford Lough (Thompson)-on Loughs Derg and Beg: (Fowler in Ireland, p. 98.)

Nyroca ferruginea (Gmel.) White-eyed Duck.or touek

Very rare winter visitor. Has occurred in Antrim and Dublin in March, 1871. (Blake Knox, in Zoologist, 1871, p. 2845.) Two on the east coast in 1879. (Fowler in Ireland, p. 101.)

Faligula marila (Linn.) Scaup.

Regular winter visitor, common on the sea shores, except in the South of Ireland.

*urigula cristata (Leach). Tufted Duck.

Regular winter visitor in small numbers, preferring fresh water. A few breed on Lough Neagh, Lough Beg, on the Shannon Lakes, and in the county Mouaghan. (Fowler in Ireland, p. 105.)

Clangula glaucion (Linn.) Golden-eye.

Regular winter visitor, frequenting especially the large inland lakes.

[The Buffel-headed Duck is believed to have been seen more than once by Sir R. Payne-Gallwey. (Fowler in Ireland, p. 110); but no specimen has as yet been obtained in Ireland.]

Earelaa glaclaus (Linn.) Long-tailed Duck.

Rare winter visitor in small numbers, chiefly occurring in the North of Ireland. 
Ferruginous huete- Has ocenred feic times. Another shol-on the Shannon neas atreone CW Wolinealn 2/st-Sancuary. 1893 (Zoologiel- hareh 1893 ). hioh halmaliel - $189,3,6.112)$ one reporteo in the Heled tan. 3re-1892 proved on escamination toter a femall Folden-ere (Hiled maroh $26 \mathrm{~m}$, 1892 ; Hesh Ral. -1892, p. 44

Ang-tailed buet Ywo ahol- in weoford haroh 1894 (hich hal:$1894,(5.158)$ 
Ming hider - hts Pobert-Pallereon (Hich hal. -1892,10. Y3) hal - an inmalice pemale has ehor- on Rathtin cilanel Conlitim in Roventer $186 /$ And was idenlified by hns Atmard Saunders. Int- Saunders does hol- nention-this speaimen

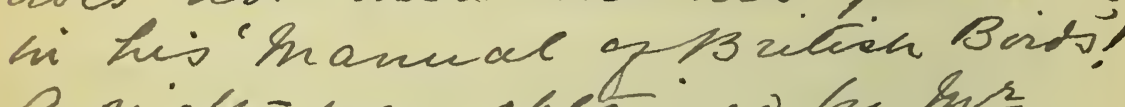
A aideln-was obcained hy hs Shereden on Achile creand 0. Inayo (Inich hal $=1593,13.14 y)$

Aurfscoler. Anotier ohol-on Achiel by hs Sheridaw.

Fibet Sooter - Inr. Robert Warren fornd a fair in heeding plimmar in bo. Stigo in the 24 t of Gune 1889 (goold 1890, fu. 354) 
somateria mollissima (Linn.) Eider Duck.

Very rare winter visitor. Has been obtained some twelve to fifteen times in Ireland. Seldom seen on fresh water, but has been twice shot on Lough Neagh.

Somateria spectabilis (Linn.) King Eider.

Sise

Extremely rare winter visitor. Has occurred four times; in the counties of Antrim, Kerry, and Dublin. (Thompson). 'The specimen from Kingstown is in the Trinity Oollege Museum.

edemia nigra (Linn.) Common Scoter.

Regular winter visitor, but local. Numerous about Belfast and Dundalk, rare in the South and West of Ireland.

ardemia rusca (Linn.) Velvet Scoter.

Rare winter visitor, occurring often far out at sea, chiefly found off the eastern coast.

EEdemia perspicillata (Linn.) Surf Scoter.



Native of America. Has occurred three times in Ireland, viz., one in Belfast Bay, 19th September, 1846. (Thompson). Another, obtained at Clontarf, Dublin, Oct., 1880, is recorded by Sir R. Payne-Gallwey. (Fowler in Ireland, p. 113.) A young malo shot at Crookhaven Harbour on the 5th November, 1888 (Zoologist, 1889, p. 32), is in the possession of Mr. R. M. Barrington.

mergus merganser (Linn.) Goosander.

Winter visitor in severe weather, and rather rare, occurring chiefly on fresh water.

*acergus serrator (Linn.) Red-breasted Merganser.

Breeds regularly on most of the large lakes in the North and West of Ireland, both on salt and fresh water, becoming much more numerous in winter on the coasts and estuaries, and wanders far up the tidal rivers.

Mergus albellus (Linn.) Smew.

Rare and uncertain winter visitor, occurring frequently on fresh, as well as salt, water. Old males are very scarce.

Mergus cucullatus (Linn.) Hooded Merganser.

Native of America. Has occurred five times in Ireland. One at Dingle Bay, in winter, about 1840. (Thompson.) One in Meath. (Watters.) Two obtained by Sir R. PayneGallwey, viz., one in Cork Harbour, Dec., 1878, and another in Korry, Jan., 1881. (Fowler in Ireland, p. 121.) A fifth, obtained in the county of Cork, is in the collection of Mr. J. G. Millais. 


\section{EXCLUDED SPECIES.}

Birds which have been reported as Irish, but whose claims to be included in our List do not appear to be sufficiently established :-

Eagle Owl.

Spotted Eagle Owl.

Tawny Owl.

Blue Thrush.

Nuthatch.

Crested Titmouse.

Bearded Titmouse.

Blue-headed Wagtail.

Tree Pipit.

Crested Lark.

Cirl Bunting.
Pine Grosbeak.

Martinico Gallinule.

Ruppell's Tern.

Cape Pigeon.

Wilson's Petrel.

Brunnich's Guillemot.

Red-breasted Goose.

Pink-footed Goose.

American Wigeon.

Buffel-headed Duck.

Membranaceous Duck.

Besides these, there are many birds common in England which have occurred so rarely in Ireland that they scarcely deserve to be included in our fauna, e.g., Reed Warbler, Nightingale, Wryneck, Red-backed Shrike, and Green Woodpecker.

Printed for Hor Majesty's Stationery Office.

By A LEx. Tuом \& Co. (Limited), 87, 88 \& 89, Abbey-street, Dubliu,

The Queen's Printing Gffico.

P. 225. 10.89 .1000 . 
Appendix

chionis alva(Kath) Sellowbilled Shewthaic A opecminer was Shot hy int Riohard Hamileor a ighthnice-tecepes al Carlingf ord Wrigh Co. Wown. 2rd Wecember 1892 (Wich halüraleil-1893pp.56, $82,151,202$; Joologicl: Samuary 1893) \& i iny unlevey thal a ratior ep the antarctie ugions of relu- Amsices areland unaidec.

Sabines Anipe- of the fifly. reven recorded epecinim. thirli-one have been oblaines in \&reand, hivenly- two in Angland, three in Sollems and one ow the conleinend(h⿻ F. 2. Barrett- Hamielón in Mish haturalid $-p$, 3) Yeventy-toro species of Amencean buis havk occurred hi Kreland. 


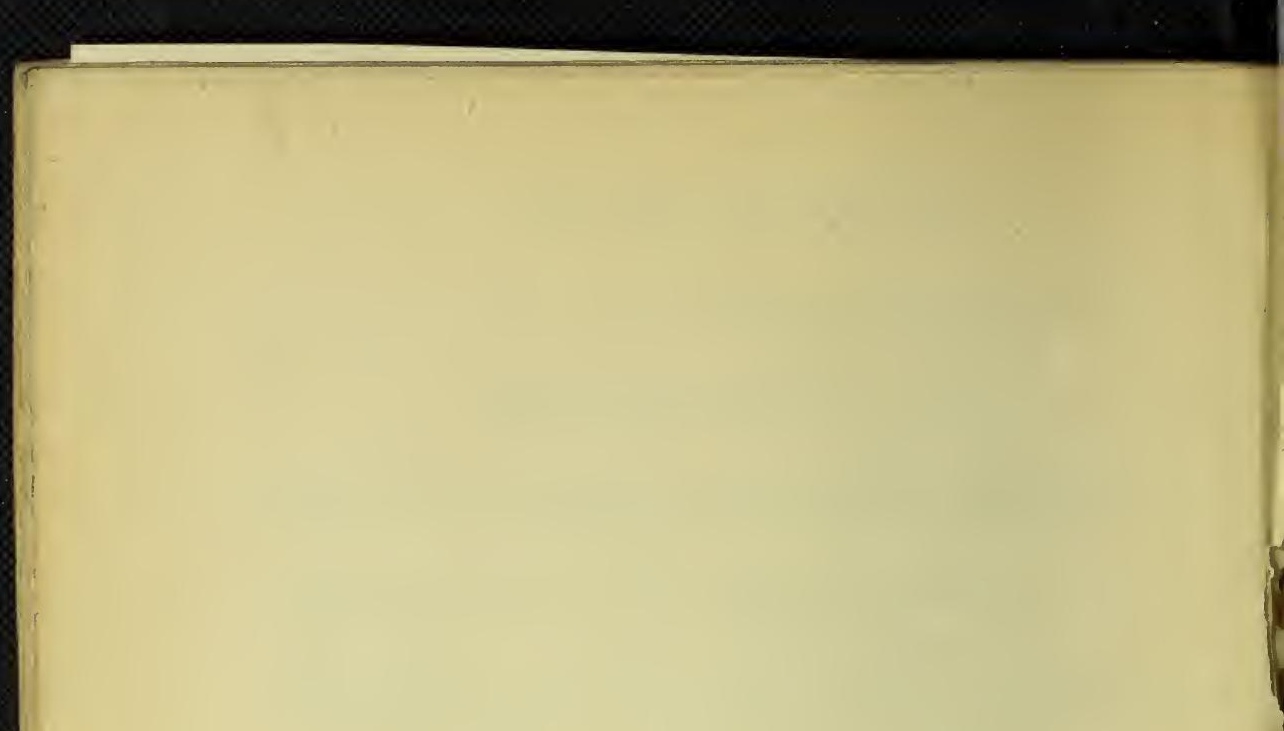




\section{NOTICE.}

The following Catalogues, Guides, \&c., which refer to the Museum and other Institutions under the Department of Science and Art are now on sale.

They may be obtained from the attendants in the Museum, or from the Hall Porter, Leinster House.

Guide to the Flectrotypes of Select Greek and Roman Coins, . . . 6d.

Mineralogical Tables, . , . . $3 d$.

Distribution of Prizes at the School of Art,

1884 and 1885 , . . $4 d$.

Catalogue of Lace, • • • . $2 d$.

Two Lectures, by Alan S. Cole, Esq., on the Art of Lace Making, . . . $2 d$.

A List of Irish Birds, by A. G. MIore, Esq.,

F.L.S., ftc., $\quad \cdot \quad \cdot \quad \cdot 4 d$.

Guide to Royal Botanic Gardens, Glasnevin, by the late D. Moore, Esq., Ph.D., E.L.S., and the late Professor W. R. M'Nab, M.D.,

Price

l.

$6 d$.

\section{In Course of Preparation.}

General Guide to the Museum of Science and Art, by the Ufficers of the Museum.

Noten-Catalogue of Vertebrate Fossils, from the Sivaliks of India, in the Science and Art Museum, Dublin. By R. Lydekker, B.A, F.G.S., F.L.S. Plate and wocdcuts, being part 4, Vol III. of Trans. Roy. Dub. Soc. Copies obtainable, price 18. 


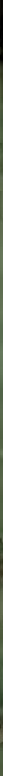




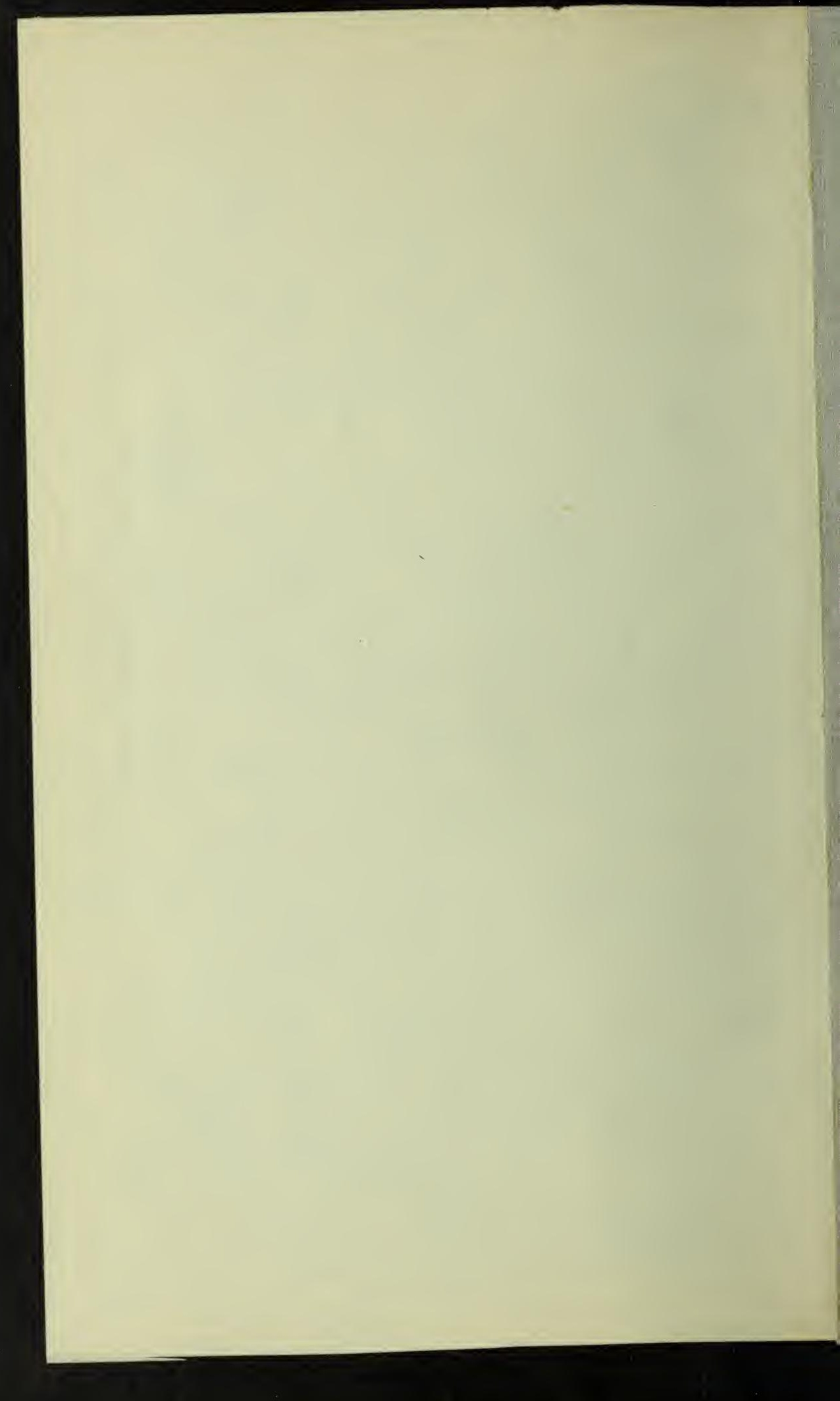

